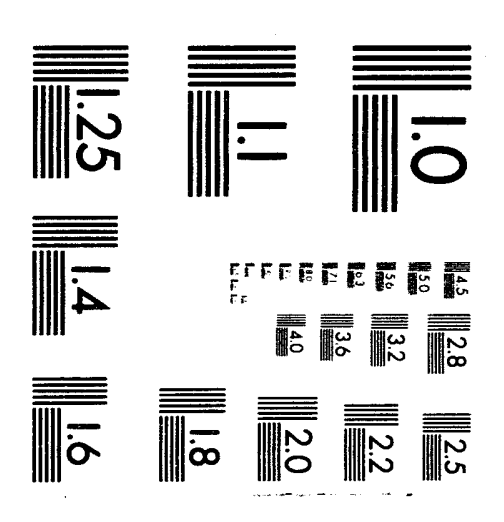



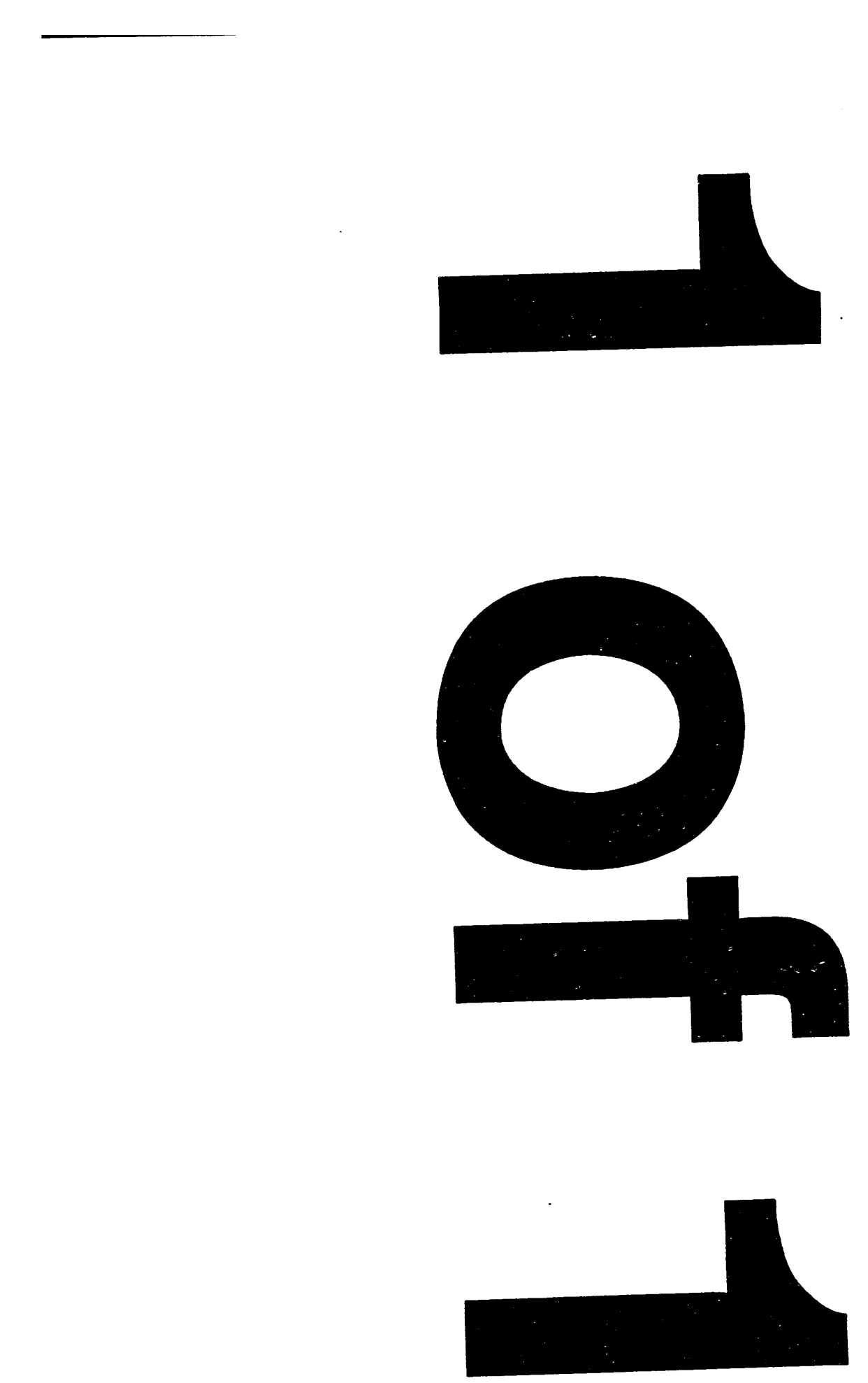


\title{
U.S. DEPARTMENT OF ENERGY URANIUM MILl TAILINGS REMEDIAL Action Ground Water Project
}

\author{
Final
}

Project Plan

December 1993

VUD

JAN 071994

OSTI

\section{DISCLAIMER}

This report was prepared as an account of work sponsored by an agency of the United States Government. Neither the United States Government nor any agency thereof, nor any of their employees, makes any warranty, express or implied, or assumes any legal liability or responsibility for the accuracy, completeness, or usefulness of any information, apparatus, product, or process disclosed, or represents that its use would not infringe privately owned rights. Reference $h_{1}$ rein to any specific commercial product, process, or service by trade name, trademark, manufarturer, or otherwise does not necessarily constitute or imply its endorsement, recommendation, or favoring by the United States Government or any agency thereof. The views and opinions of authors expressed herein do not necessarily state or reflect those of the United States Government or any agency thereof. 


\section{U.S. DEPARTMENT OF ENERGY}

\section{URANIUM MILL TAILINGS REMIEDIAL ACTION GROUND WATER PROJECT}

(MP-AL-4)

\section{FINAL}

\section{PROJECT PLAN}

December 1993 
TABLE OF CONTENTS

Section

Page

1.0 MISSION NEED AND ObJECTIVES $\ldots \ldots \ldots \ldots \ldots \ldots \ldots \ldots \ldots \ldots \ldots$

1.1 Mission nerd ............................ 1-1

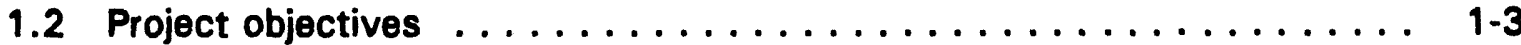

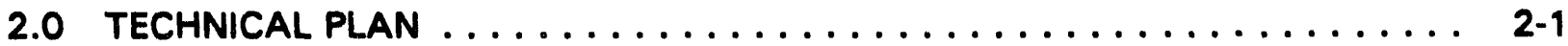

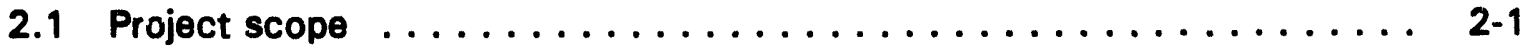

2.2 Project strategy .......................... 2-1

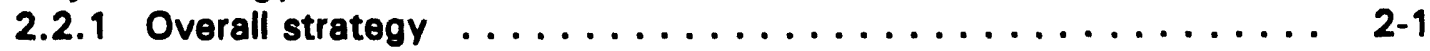

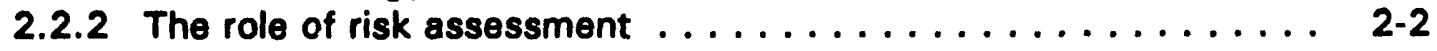

2.2.3 Observational approach ................... 2-2

2.2.4 Programmatic documents ................. 2-3

2.2.5 NEPA compliance ....................... 2-4

2.2.6 Compliance strategies for meeting ground water standards . . . . 2-4

2.2.7 Project phases . . . . . . . . . . . . . . . . 2-7

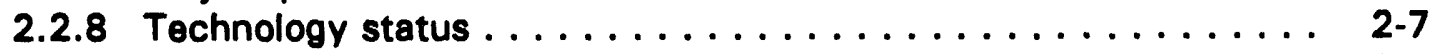

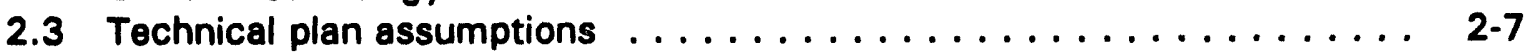

2.4 Work breakdown structure $\ldots \ldots \ldots \ldots \ldots \ldots \ldots \ldots \ldots \ldots \ldots . \ldots \ldots$

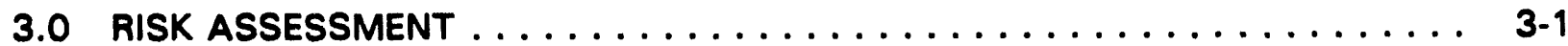

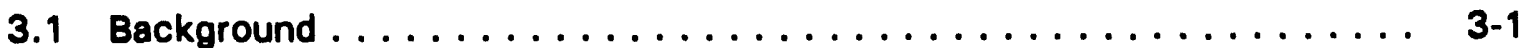

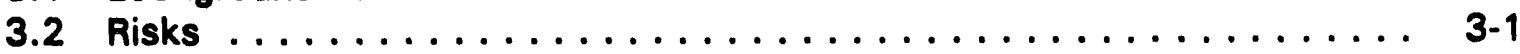

3.3 Methodology ........................... 3-2

3.4 Application of risk (subproject contingency and project risk and

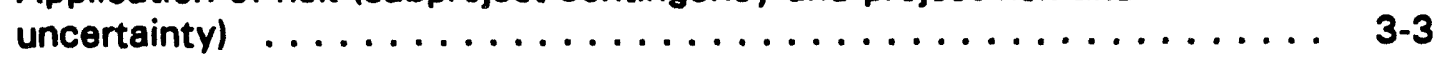

4.0 MANAGEMENT APPROACH $\ldots \ldots \ldots \ldots \ldots \ldots \ldots \ldots \ldots \ldots \ldots \ldots \ldots$ 4-1

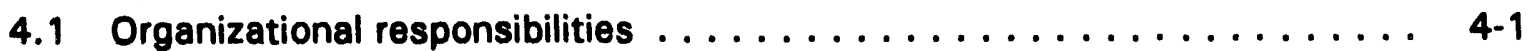

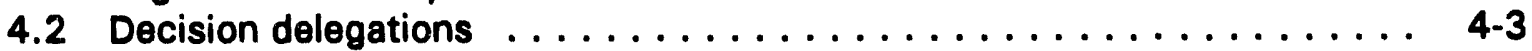

4.3 Project control system . . . . . . . . . . . . . . . . . . 4-4

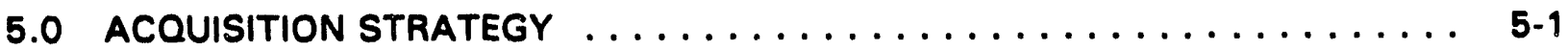

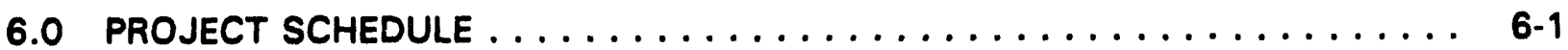

6.1 Background .............................. 6-1

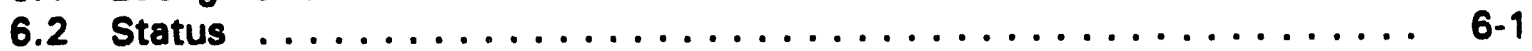

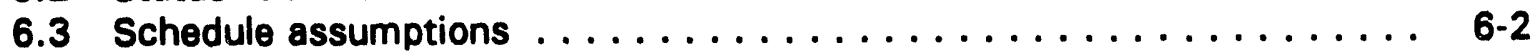

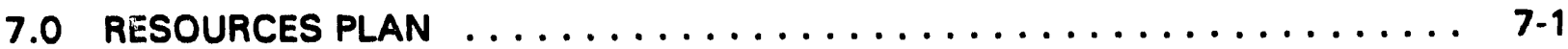

7.1 Costs ........................... $7-1$

7.2 Manpower .......................... $7-1$

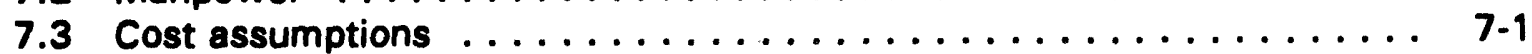

8.0 CONTROLLED ITEMS/BASELINES $\ldots \ldots \ldots \ldots \ldots \ldots \ldots \ldots \ldots \ldots \ldots$ 
TABLE OF CONTENTS (Concluded)

Section

Page

9.0 SUBMISSIONS AND APPROVALS $\ldots \ldots \ldots \ldots \ldots \ldots \ldots \ldots \ldots \ldots$

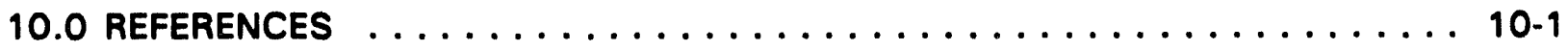

\section{ATTACHMENTS}




\section{LIST OF EXHIBITS}

\section{Exhibit}

Page

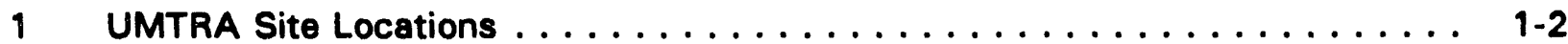

2 UMTRA Ground Water Project work breakdown structure . . . . . . . . . . 2-9

3 UMTRA Ground Water Project organization $\ldots \ldots \ldots \ldots \ldots \ldots \ldots \ldots$

4 Resource requirements plan by activity data sheet $(\$ M) \ldots \ldots \ldots \ldots$ 


\section{LIST OF ACRONYMS AND ABBREVIATIONS}

\section{Acronym}

$A C L$

ADS

AEA

AL

BLM

CERCLA

CFR

$\operatorname{CSCSC}$

DOE

DOI

DOO

EA

EH

EM

EPA

ESAAB

ESHP

FONSI

FR

FY

FYP

HO

IPMS

IRB

LTSM

LTSP

$M C L$

MP

NEPA

NRC

OGC

OMB

OSHA

PCS

PEIS

PL

PMCS

PSO

QA

QAIP

\section{Definition}

alternate concentration limit

activity data sheet

Atomic Energy Act

Albuquerque Operations Office

Bureau of Land Management

Comprehensive Environmental Response, Compensation, and Liability

Act

Code of Federal Regulations

Cost and Schedule Control Systems Criteria

U.S. Department of Energy

U.S. Department of the Interior

data quality objective

environmental assessment

Office of Assistant Secretary for Environment, Safety, and Health

Office of Assistant Secretary for Environmental Restoration and Waste

Management

U.S. Environmental Protection Agency

Energy Systems Acquisition Advisory Board

Environmental, Safety, and Health Plan

finding of no significant impact

Federal Register

fiscal year

Five-Year Plan

DOE Headquarters

Integrated Project Management System

Internal Review Budget

long-term surveillance and maintenance

long-term surveillance plan

maximum concentration limit

Major Project

National Environmental Policy Act

U.S. Nuclear Regulatory Commission

Office of General Council

Office of Management and Budget

Occupational Safety and Health Administration

Project Control System

programmatic environmental impact statement

Public Law

Project Management Control System

Program Secretarial Officer

quality assurance

Quality Assurance Implementation Plan 


\section{LIST OF ACRONYMS AND ABBREVIATIONS (Concluded)}

$\begin{array}{ll}\text { Acronym } & \text { Definition } \\ \text { R\&TD } & \text { research and technology development } \\ \text { RAC } & \text { Remedial Acticn Contractor } \\ \text { RAP } & \text { remedial action plan } \\ \text { RCRA } & \text { Resource Conservation and Recovery Act } \\ \text { ROCS } & \text { Regulatory Oversight and Compliance Support } \\ \text { RRM } & \text { residual radioactive material } \\ \text { SAFER } & \text { streamlined approach for environmental restoration } \\ \text { SRP } & \text { standard review plan } \\ \text { SWDA } & \text { Solid Waste Disposal Act } \\ \text { TAC } & \text { Technical Assistance Contractor } \\ \text { TAGR } & \text { Technical Approach to Ground Water Restoration } \\ \text { TEC } & \text { total estimated cost } \\ \text { TPC } & \text { total Project cost } \\ \text { UMTRA } & \text { Uranium Mill Tailings Remedial Action } \\ \text { UMTRCA } & \text { Uranium Mill Tailings Radiation Control Act } \\ \text { URS } & \text { Uniform Reporting System } \\ \text { USC } & \text { United States Code } \\ \text { WBS } & \text { work breakdown structure }\end{array}$




\subsection{MISSION NEED AND OBJECTIVES}

\subsection{MISSION NEED}

The United States Congress passed the Uranium Mill Tailings Radiation Control Act (UMTRCA) in 1978 (42 USC $\$ 7901$ et seq.), hereinafter referred to as the "Act," in response to public concerns about potential health hazards from exposure to uranium mill tailings over long periods of time. The Act authorized the U.S. Department of Energy (DOE) to stabilize, dispose of, and control uranium mill tailings and other contaminated materials at 24 uranium mill processing sites (see Exhibit 1). The Act designates the inactive processing sites (Title I) (whether uranium from these facilities was sold to the United States Government or not), authorizes the DOE Uranium Mill Tailings Remedial Action (UMTRA) Project, mandates remedial action in accordance with standards prescribed by the U.S. Environmental Protection Agency (EPA) (see Attachment 1), and directs the DOE to enter into cooperative agreements with the affected states and Indian tribes.

The UMTRA Amendments Act (PL 100-616, 1988), hereinafter referred to as the "Amendments Act," authorized the DOE to extend without limitation the time frame needed to complete ground water compliance activities at the processing sites required by the EPA standards codified in 40 CFR Part 192 (1988). In addition, as a result of the Amendments Act, the U.S. Nuclear Regulatory Commission (NRC) will allow licensing of disposal sites where the uranium mill tailings are stabilized within the boundaries of the processing site to occur in two steps, if needed, to avoid lengthy delays in licensing the disposal sites.

In addition to meeting the requirements of the proposed EPA ground water cleanup standards, the DOE will also follow the guidance contained in DOE Order 5400.1 for ground water protection. This order requires the establishment of environmental protection programs to ensure compliance with all applicable federal, state, and local environmental protection laws and regulations, executive orders, and DOE policies.

To fulfil the mission of the Act, the DOE has established two projects under the UMTRA Project Office. The UMTRA Surface Project began remedial action in 1983 and is currently in the construction phase. It has been designated as a Major System Acquisition, and a separate UMTRA Project plan has been prepared for that portion of the mission. This project plan covers the UMTRA Ground Water Project, herein referred to as the "Project," which has been designated as a Major Project (MP). Funding for this Project was first received in fiscal year (FY) 1991.

In August 1992, a presentation was made to the Assistant Secretary for Environmental Restoration and Waste Management (EM), who acts in the capacity of the Program Secretarial Officer (PSO), to request Approval of 


\section{UMTRA SITE LOCATIONS}

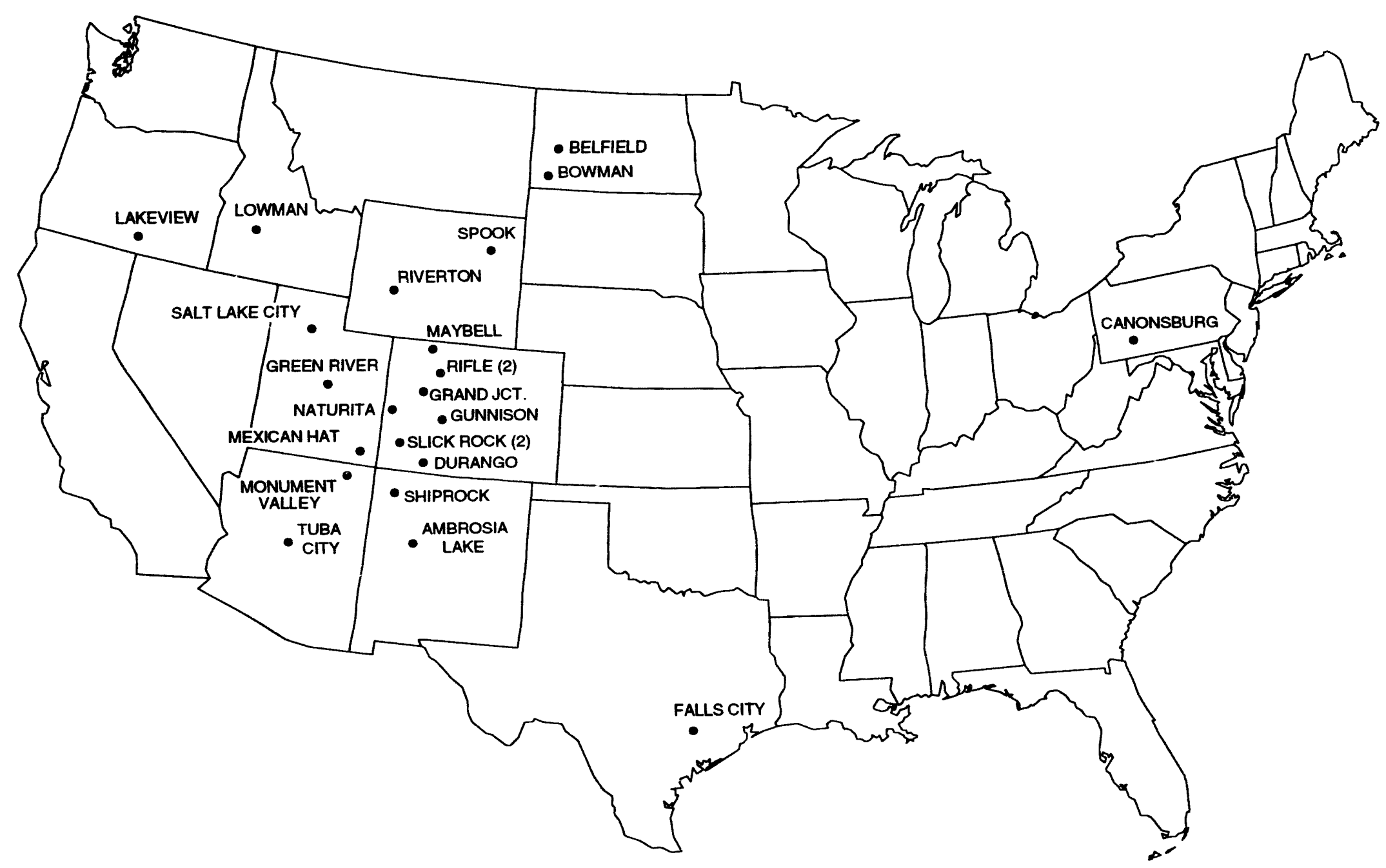


mission need. Approval of mission need was subsequently received by the authority delegated to the Deputy Assistant Secretary for Environmental Restoration (EM-40) on September 1, 1992. A baseline that closely supported this presentation was subsequently approved by EM-40 in October 1992 as the Baseline Approved for Use. Since then, more current Project data were used to create the FY1995 Internal Review Budget (IRB). Therefore, although not yet officially validated by EM-40 as the new baseline, this Project plan is supported by the EM-40 FY1995 IRB.

\subsection{PROJECT OBJECTIVES}

Technically sound and cost-optimized ground water compliance activities will be selected that will result in protection of human health and the environment and full compliance with the proposed EPA ground water cleanup standards in 40 CFR Part 192 (1988). A programmatic environmental impact statement (PEIS) now being developed will be used as a decision-making document to determine the Project-wide ground water compliance strategy. The overall technical, schedule, and cost objectives of the Project, as stated below, are based on the strategy proposed in the PEIS. These objectives are driven directly by the Project's mission need and regulatory framework. Technical, schedule, and cost planning assumptions that support these general objectives are described in Sections 2.3, 6.3, and 7.3, respectively.

- Ensure that environmental factors are adequately addressed in the development and implementation of remedial action plans and that provisions of the National Environmental Policy Act (NEPA) (42 USC $\$ 4321$ et seq.), as implemented by the Council on Environmental Quality (40 CFR $\$ \$ 1500-1508$ [1978]) regulations and DOE guidelines, are satisfied.

- Obtain the cooperation of the affected stakeholders, including states, Indian tribes, and property owners, in accomplishing the mission of the Project.

- Carry out a public participation program that encourages stakeholder involvement in the Project's decision-making process.

- Carry out Project activities in a safe and environmentally sound manner in accordance with EPA standards and applicable federal and state laws.

- Return all former processing sites to a condition suitable for unrestricted use and complete licensing at sites where contamination is stabilized in place or stabilized on the site.

- Complete the Project by FY2014. Although not tied to the Act, the Project schedule objective is to complete ground water compliance at the last site by the year 2014, with provisions for institutional controls, natural flushing, and verification monitoring. This objective is supported by the most current federal budget, which at the time of this writing, is the FY1995 IRB. 
- Complete the Project within the projected total estimated cost (TEC) of $\$ 691.6 \mathrm{M}$ (or $\$ 673.4 \mathrm{M}$ federal share). This TEC is based upon the FY1995 IRB.

- Work with regulators and stakeholders to reduce costs of achieving compliance.

Due to the early stage of the Ground Water Project, it is highly probable that the technical requirements, scope, TEC, and schedule will change from this Project plan. The Project has not yet completed its PEIS; therefore, all estimates are planning estimates or the equivalent of preconceptual design estimates. The Project scope is subject to change, if there are changes to the final EPA regulations, regulatory guidance from the NRC, application of the observational approach, general technical and regulatory assumptions, or stakeholder influence. Significant changes to the technical requirements, scope, TEC, or schedule will be reflected in future modifications to this document. 


\subsection{TECHNICAL PLAN}

\subsection{PROJECT SCOPE}

The scope of the Project is to develop and implement a ground water compliance strategy for all 24 UMTRA processing sites. The compliance strategy for the processing sites must satisfy requirements of the proposed EPA ground water cleanup standards in 40 CFR Part 192, Subparts B and C (1988). This scope of work will entail the following activities, on a site-specific basis:

- Development of a compliance strategy based upon modification of the UMTRA Surface Project remedial action plans (RAP) or development of Ground Water Project RAPs with NRC and state or tribal concurrence on the RAP.

- Implementation of the RAP to include establishment of institutional controls, where appropriate.

- Institution of long-term verification monitoring for transfer to a separate DOE program on or before the Project end date.

- Preparation of completion reports and final licensing on those sites that will be completed prior to the Project end date.

\subsection{PROJECT STRATEGY}

\subsubsection{Overall strateay}

As discussed in Section 1.2, the PEIS will be used as a decision-making document to determine the Project-wide ground water compliance strategy. The programmatic approach proposed in the PEIS is evaluation of specific conditions at each site and selection of a compliance strategy for each site that will ensure compliance with the appropriate EPA standards. These proposed compliance strategies, summarized in Section 2.2.6 of this document, reflect the variety of ground water conditions anticipated at the UMTRA sites and range from no further action being required to engineered remedial actions. The compliance strategy at each site will be developed in site-specific environmental assessments (EA) tiering from the programmatic framework defined in the PEIS.

Project optimization will be continuously pursued to ensure that compliance with the EPA standards and protection of human health and the environment will be accomplished at the lowest cost possible. Project optimization involves considering the total life-cycle cost in the selection of compliance strategies, combining active and passive strategies when cost benefits and compliance can be achieved, and pursuing innovative technical approaches that will achieve compliance at reduced cost. The observational approach is a key element of program optimization and will ensure that cost-effective decisions are made to 
implement selected strategies. The observational approach is further discussed in Section 2.2.3.

DOE's overall strategy not only provides maximum value for each dollar spent but is alsc rully consistent with the intent of the EPA, as expressed in the preamble to the ground water standards:

Nonetheless, it is clearly desirable and appropriate to apply the most cost-effective remedies available to meet these standards at each site, and we anticipate the DOE will make such choices in choosing the remedies it applies to satisfy these standards.

These and other key elements of the DOE's approach to implementing the Project are discussed further below.

\subsubsection{The role of risk assessment}

For the following reasons, risks to human health and the environment will be evaluated beginning in the earliest stages of the Project:

- Preliminary risk evaluations will be used to prioritize sites, scope data collection, and determine if a site presents immediate health risks.

- Where needed, baseline risk assessments will fully integrate and interpret demographic, geographic, physical, chemical, and biological factors at each site to determine the extent of actual or potential harm. This information is useful in determining the need for remedial action.

- Risk evaluation of remedial alternatives will be performed to evaluate risks to human health, including worker safety, and the environment that are associated with the various remedial strategies. For example, this process may include evaluating the environmental impacts of an active remedial action strategy.

- After remediation, a risk assessment update may be conducted to verify that the action taken is protective of human health and the environment.

\subsubsection{Observational approach}

The Project will implement an observational approach that reflects the DOE's streamlined approach for environmental restoration (SAFER). SAFER recognizes yet accommodates the uncertainties related to remediation at hazardous waste sites. Traditional approaches to uncertainties can lead to unrealistic data collection activities at sites where it is not possible, desirable, or necessary to fully characterize the site before remedial activities begin. The observational approach uses existing site data to create a conceptual model of site conditions and applicable ground water compliance strategies based on the most probable 
site conditions. Reasonable deviations from these site conditions will be identified, as well as the critical parameters that will be observed to detect potential divergence from the remediation goals. Contingency plans will be developed to deal with potential divergences. This process allows a reasonable investigation to be performed and a contingency plan to be prepared for detecting and responding to the new information that will invariably improve the understanding of the site during remediation. The observational approach has been successfully applied to other environmental projects and is consistent with the regulatory framework of both the Comprehensive Environmental Response, Compensation, and Liability Act (CERCLA) and Resource Conservation and Recovery Act (RCRA).

\subsubsection{Proarammatic documents}

The four major technical programmatic documents discussed below will guide the Project in the performance of Project activities. Supporting plans and documents will be developed in a tiered manner from the following in-progress documents and from the Technical Approach to Ground Water Restoration (TAGR) (DOE, 1993a):

- "Programmatic Environmental Impact Statement." Will provide an objective decision-making methodology for selecting a tiered compliance strategy. More information is provided in Section 2.2.5.

- "Quality Assurance Implementation Plan" (QAIP). Will address quality assurance (OA) issues. It will provide QA specifications for the collection of environmental samples and data and for the analysis of the samples. The QAIP will specifically address data quality objectives (DOO), including statistical and numerical techniques, to assist in directing data collection and analysis. Quality issues associated with data and samples related to geology, hydrology, chemistry, biology, and engineering are covered by the QAIP.

- "Environmental, Safety, and Health Plan" (ESHP), "Public Information Plan," and "Public Participation Plan." Will specify commitment to protection of the environment, health, and safety and outline a proactive public involvement program. These three UMTRA plans are applicable to both the Surface and Ground Water Projects.

- Technical Approach to Ground Water Restoration (DOE, 1993a). Will provide a technical overview of how the Project will be conducted. The TAGR covers the regulatory basis and requirements for compliance and provides a framework for the field activities to meet those requirements. The field activities will follow the observational approach. The TAGR is directed toward the technical and management staffs of the UMTRA Project Office and the Technical Assistance Contractor (TAC), as well as toward the staffs of regulatory agencies and stakeholders. 


\subsubsection{NEPA compliance}

The approach to NEPA compliance is a two-phased plan that will provide an appropriate and responsive vehicle for meeting NEPA requirements. In the first phase, the PEIS will propose a Project-wide ground water compliance strategy (proposed action), consider alternatives to the proposed action, and assess the impacts of the alternatives (including the proposed action). Any alternatives identified by the public during scoping meetings will be analyzed in the PEIS, and configuration of the final proposed action could change. The use and acceptance of a PEIS as part of the NEPA decision-making process is well documented. The DOE and other federal agencies have successfully used the PEIS process as a means to facilitate program planning, provide an early assessment of potential problems, assess programmatic impacts, and reduce the overall scope of subsequent NEPA documents. The PEIS is also valuable for informing regulators, states, and tribes of the approach to ground water compliance early in the process. In addition, it is an important mechanism for positively and proactively involving the public in the DOE decision-making process at an early stage. Approval to go forward with the PEIS was granted in an Action Description Memorandum on February 27, 1992.

The PEIS will accomplish the following:

- Describe general conditions at the 24 UMTRA sites.

- Analyze programmatic impacts of the proposed action and other alternatives.

- Identify and evaluate appropriate methods of ground water remediation.

- Describe the risk assessment methodology (see Section 3.0, Risk Assessment).

The second phase of NEPA compliance will be to prepare site-specific EAs. These EAs will tier off the PEIS; i.e., the specific ground water compliance strategy for a given site will be determined from the PEIS proposed action and site-specific conditions. The EAs will also assess site-specific impacts.

\subsubsection{Compliance strategies for meeting ground water standards}

\section{Introduction}

The proposed EPA ground water standards establish prescriptive, numerical concentration limits based on maximum concentration limits $(M C L)$ or background concentrations for those contaminants which were expected to be associated with the uranium milling processes that occurred at UMTRA sites. Alternate concentration limits $(A C L)$ may be established for contaminants that do not have an established $M C L$ or when it can be demonstrated that the specific contaminant poses no significant current or potential future risk to 
human health or the environment. Supplemental standards may be established in several instances, most notably when it can be shown that the affected ground water serves no beneficial use. The data must demonstrete that the supplemental standards will come as close to meeting the otherwise applicable standards as is reasonably achievable under the circumstances and that human health and the environment are protected.

The compliance strategy selected for each site will be consistent with the proposed action in the PEIS, will be directed toward satisfying the applicable EPA standards, and will reflect the results of site-specific risk evaluations. The compliance strategies listed below reflect the wide range of potential actions that may be required to achieve compliance with the EPA standards and protect human health and the environment. These strategies are sequenced in the Project logic diagram (see Attachments 2 and 3). They will be presented in the PEIS and are summarized below.

- No further action compliance demonstration.

- Passive remediation.

- Active remediation.

- Combination strategies.

\section{Ne further action compliance demenstration}

At processing sites where the tailings have been removed or stabilized and no ground water contamination exists, remedial action is not needed. At these sites, the DOE will prepare appropriate NEPA documentation to formally evaluate the alternatives. If no further action is warranted, a RAP will be prepared to document the besis for compliance with applicable standards. The RAP will be submitted to the NRC and the appropriate state and/or tribe for review and concurrence. Alternatively, a modification to the previously issued surface RAP may be used; it will require the same concurrence.

At sites where ground water contamination exists but existing site conditions warrant application of supplemental standards, the same approach as described above will be followed. Supplemental standards may be applicable at those sites where 1) ground water is classified as a limited-use resource, 2) remediation of ground water is technically impracticable, 3) no remedial action solution is known, 4) ground water remediation would cause excessive environmental harm, or 5) remedial action would present an unacceptable risk to workers or the public. An additional approach to no further action compliance demonstration would be to apply for ACLs. This would primarily be used for constituents without MCLs. 


\section{Passive remediation}

At sites where ground water contamination levels exceed applicable EPA standards, passive remediation (i.e., natural flushing) will be the preferred strategy, provided it can be demonstrated that contaminant concentrations will be reduced naturally to ACLs, MCLs, or background within 100 years and that human health and the environment will be protected during this period. Satisfactory institutional control of water use and a ground water monitoring program will be maintained throughout the remediation period. Appropriate NEPA and RAP documentation will be prepared to document the environmental considerations and technical basis for the future projected compliance with applicable EPA standards. When MCLs or background concentrations have been achieved, a completion report will be prepared.

\section{Active remediation}

At some sites, it may be determined that a passive strategy will not achieve compliance with applicable EPA standards or provide adequate protection of human health or the environment. In these cases, active or engineered ground water remediation strategy must be considered. The options currintly identified that are most applicable to UMTRA sites are listed below. These options may be used individually or in combination.

- Plume management and containment.

- Secondary source remediation (hot-spot removal).

- Bioremediation.

- Extraction and land application.

- Other innovative technologies.

In addition to development of the NEPA and RAP documentation discussed for the previous strategies, active remediation will require a formal design, installation of wells and equipment, and an operating period. The observational approach (see Section 2.2.3) will be followed to ensure that remedial actions are accomplished in a phased manner and to ensure that each phase is implemented with a solid understanding of the ground water system's response to previous activities.

\section{Combination strategy}

A combination of active and passive strategies will be considered when a passive strategy alone will not achieve compliance with the EPA standards. For example, active remediation of a hot spot over a relatively short time may significantly shorten the time required to further reduce concentrations to within the applicable standards by natural flushing. In keeping with the Project optimization approach discussed in Section 2.2.1, every effort will be made to plan for and implement a transition from active to passive strategies as soon as compliance with the EPA standards can be technically demonstrated and appropriate institutional controls can be put in place (or continued) to adequately 
protect human health and the environment for the extended period of remediation.

\subsubsection{Project phases}

The Project phases, along with the activity, product, and decision required in each phase, are outlined in Attachment 4 and support the work breakdown structure (WBS) depicted in Attachment 5. In summary, the Project can be viewed as having the following four major phases and associated elements:

\begin{tabular}{ll}
\hline \multicolumn{1}{c}{ Phase } & \multicolumn{1}{c}{ Products and services } \\
\hline Comparative analysis of restoration alternatives & Site assessment/characterization \\
& NEPA \\
& Restoration alternatives assessment \\
Remedial action planning and desion & Site observational work plan \\
& RAP \\
& Conceptual and final design \\
Implementation of RAP & Passive compliance strategy \\
& Active compliance strategy \\
& Combination strategy \\
Monitoring and licensing & Verification monitoring \\
& Completion reports \\
& Final licensing \\
\hline
\end{tabular}

\subsubsection{Technology status}

Existing technologies for active ground water remediation are being assessed to determine methods that may be applicable to achieve compliance with ground water cleanup standards. At this time, the technical plan for the Project is adequately supported by existing technology. Innovative technologies that are potentially applicable to UMTRA sites will be evaluated and considered.

\subsection{TECHNICAL PLAN ASSUMPTIONS}

The following key assumptions have been made in developing the technical plan:

- The programmatic approach proposed in the PEIS will be accepted by the stakeholders as the decision-making process for determining the overall ground water compliance strategy for the Project.

- Site-specific risk assessments will not indicate that action is required beyond that required for compliance with the EPA standards. 
- The Project will be successful in gaining concurrence on the application of a cost-effective approach to compliance with regulatory requirements and protection of human healtr: and the environment.

- The proposed EPA standards will be finalized with no substantial changes.

- There is no current use of contaminated ground water which represents an immediate risk to human health or the environment; the compliance strategy is for mitigating future Dotential use.

- Local governing bodies will not enforce stricter standards than the EPA's UMTRA standards.

- Ground water remediation will not be required for any of the vicinity properties.

- Long-term verification monitoring will be conducted through another project after the Project end date.

\subsection{WORK BREAKDOWN STRUCTURE}

The Project WBS used by EM-40 is shown in Exhibit 2. The installation level represents the overall Project. The summary subproject level contains the major Project work elements. The subproject level reflects the work elements grouped by Five-Year Plan (FYP) activity data sheets (ADS). This is the WBS approved in the Baseline Approved for Use which was presented to EM-40 in October 1992. Attachment 5 extends the WBS below the subproject level by site and by activity. 


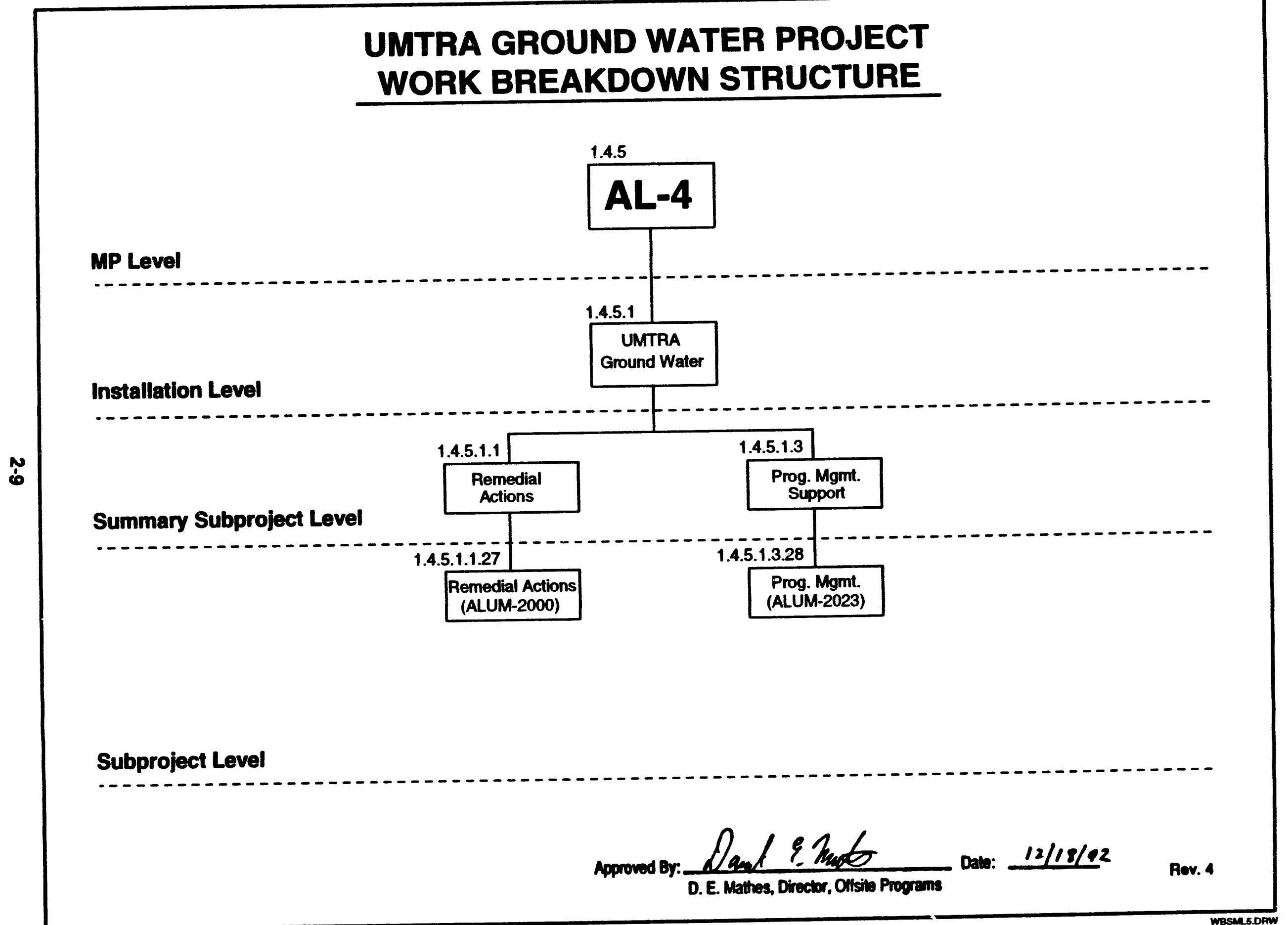




\subsection{RISK ASSESSMENT}

\subsection{BACKGROUND}

Project assumptions, as addressed in Sections 2.3, 6.3, and 7.3 of this Project plan and Section 3.0 of the UMTRA 1992 Roadmap (DOE, 1993b), provide the basis for identification of risks or issues. Also contributing to the risk development process is the fact that the Ground Water Project, unlike the UMTRA Surface Project, is not a mature project at this writing. Interface between the DOE, states and tribes, and the NRC are still being established.

Risks were initially identified by the DOE Project Office; several of these risks were identified in the Roadmap. Comments were solicited from DOE Headquarters (HO) and DOE Albuquerque Operations Office (AL) before finalization. The Roadmap breaks out several risks (issues) into primary, sel:ondary, and tertiary issues. The risks were prioritized based on the FYP prioritization. The Project risks are considered priority 3 because the Project is needed to comply with existing federal laws and regulations but not necessarily to prevent near-term adverse impacts to the public or the environment, as is the UMTRA Surface Project. Attachment 6 lists the identified risks that could impact both the scope and cost of accomplishing the planned program. Some of these risks are also identified in the Roadmap.

\section{$3.2 \quad$ RISKS}

At this stage of the Ground Water Project, the overall Project risk is considered high. Component risks are delineated in Attachment 7. The identified risk areas include the following:

- The participation in and the acceptance by the public, states, and tribes to the proposed decision-making process and resulting solutions, i.e., the targeted compliance strategy at each site (an identified risk in the FY1992 Roadmap).

- Regulatory impacts.

- The involvement of multiple participants - NRC, EPA, and the affected states and tribes (an identified risk in the FY1992 Roadmap).

- State funding (an identified risk in the FY1992 Roadmap) (see Section 4.1).

- Potential federal funding perturbations (an identified risk in the FY1992 Roadmap).

- Land access.

- Safety. 
- Change in technical requirements.

- Increased costs.

- Delays to schedule.

The greatest Project uncertainty at this time concerns public, state, and tribal acceptance of the currently targeted regulatory compliance strategies. UMTRA Surface Project history illustrates that publicly unacceptable solutions will not be tolerated. Gaining stakeholder acceptance on the targeted compliance strategies is essential to meeting the Project's proposed cost and schedule baselines. This uncertainty accounts for the largest share of the Project's identified contingency.

Ground water cleanup and regulatory standards for the Project are established by EPA. At present, the Project's goals are to comply with the proposed EPA ground water standards published in 1987; the actions proposed in the PEIS are designed to support those standards. NRC will administer the standards and function as the regulatory agency. In addition, states and tribes participating in the Project will have concurrence on compliance strategies. Because of the multiplicity of approval and standard setting regulatory actions, accomplishing the targeted remediation strategies will be difficult and somewhat unpredictable. Adherence to new and more stringent state or tribal regulations than those already planned for is another uncertainty for which the Project estimates use of contingency funds.

In addition to political pressures from the public and from state agencies, the currently planned program assumes that the states will cost-share in the Project (see Section 4.1). Delays in state-share funding or the states' refusal to participate in the Project will affect the timing and ultimate cost of the program as it is planned. Similarly, perturbations and delays in federal funding will impact the ultimate cost of the Project. Neither risk is accounted for in the Project risk and uncertainty contingency.

Access to existing site wells or the inability to drill new wells due to lack of access is an obvious risk that could delay site characterization and the ensuing compliance strategy. Changes in currently understood plume size and contaminant concentrations are considered to have a low risk rating. Safety, technical requirements, cost, and schedule risks are summarized in Attachment 6.

\subsection{METHODOLOGY}

To evaluate the potential impacts of the above-identified risks of public acceptance and political pressures, risk calculations were performed based on knowledge of public and political attitudes observed during the UMTRA Surface Project remediation activities. 
Previous Project cost estimates were based on worst-case assumptions (pump and treat option at most sites). The present plan has been optimized to reflect the most cost effective strategies at each site. Therefore, the difference between the two approaches forms the basis for the identified contingency.

Knowledge of site conditions and experience with the public and associated local officials during the surface remediation Project were used to determine the likelihood of accomplishing the targeted solution (compliance strategy) for each site. Site-by-site probability factors were then assigned to each WBS element. Some WBS elements require the same level of effort ragardless of the ultimate compliance strategy selected, while others can be dramatically affected by the selected strategy.

\subsection{APPLICATION OF RISK (SUBPROJECT CONTINGENCY AND PROJECT RISK AND UNCERTAINTY)}

The site-specific upper limit cost estimate for performing an active type of remedial action was developed first. This higher estimate, also referred to as the alternate approach, was compared to the more optimized, or preferred approach, estimate for selected sites. A percentage if this incremental increase in costs was included in the budget estimate as subproject contingency and was allocated to the appropriate contractor and WBS for incorporation into the TEC. Nonsite-specific work associated with performing the alternate approach was also added as Project risk. The method used to incorporate and allocate risk was determined to be a reasonable planning level for cost increases above the aggressive target goals of the Project. Project risk and uncertainty contingency were also allocated to cover unknown unknowns for work associated with the more aggressive, targeted remedial action strategy.

The risk calculations account for the probable successes and failures of public acceptance to the proposed ground water compliance strategy. Potential changes in the EPA ground water standards or concurrence by the NRC and the states on the proposed compliance strategy have not been accounted for. 


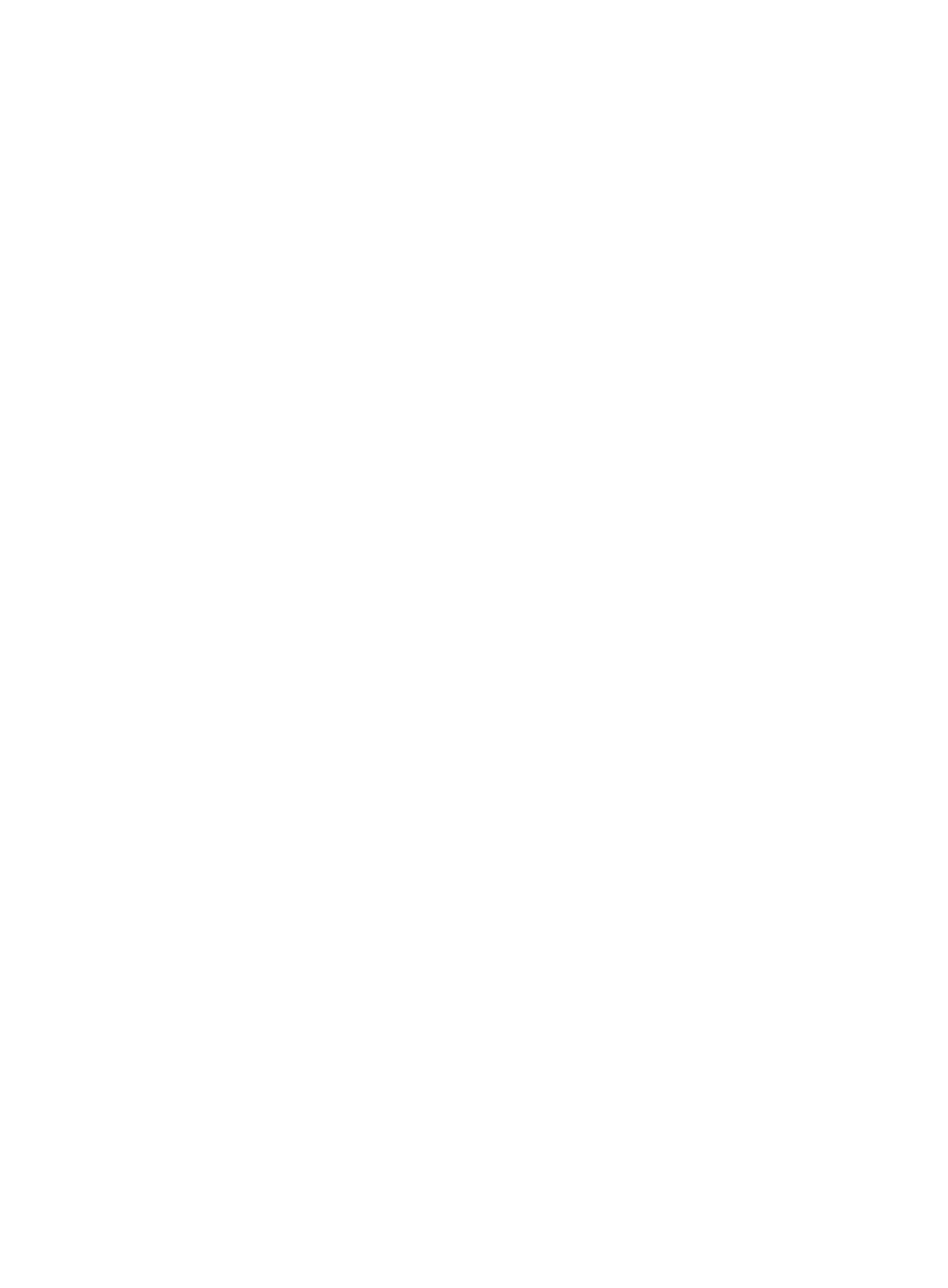




\subsection{MANAGEMENT APPROACH}

\subsection{ORGANIZATIONAL RESPONSIBILITIES}

Several federal entities are responsible for legislative implementation of the Act. Exhibit 3 summarizes these organizational responsibilities provided for in the Act. Specific assignments are discussed below.

The 1978 Act required EPA to promulgate standards for both active and inactive uranium processing sites for the protection of public health, safety, and the environment from radiological and nonradiological hazards associated with residual radioactive material (RRM). The standards were published in January 5 , 1983, and became effective March 7, 1983. However, in September 1985, that portion of the standards dealing with ground water contamination was remanded to EPA for modification to ensure consistency with applicable RCRA provisions and Title II regulations. The proposed final standards were issued in September 1987. In May 1991, the EPA submitted revised standards to the Office of Management and Budget (OMB) for review. However, the DOE is required by Section 275 of the Atomic Energy Act (AEA) (42 USC 2011 et seq.) to continue to use the proposed standards of 1987 until final standards are promulgated.

The NRC is the regulatory agency responsible for RAP concurrence on ground water compliance at the processing sites. The NRC will provide a standard review plan (SRP) that will include the standard format and content (NRC, 1989) guide to the DOE for the Project. The NRC requirements and expectations will be identified in the SRP for expediting their review and concurrence with concepts, plans, and documents during the Ground Water Project.

The Act also stipulates that the U.S. Department of the Interior (DOI) must be consulted concerning sites on Indian lands and that the U.S. Department of Justice will determine the liability of owners and operators of the designated sites for remedial action costs.

Within the DOE, three organizations are assigned responsibilities stipulated in the Act: the Office of General Counsel (OGC); the Office of Assistant Secretary for Environment, Safety, and Health (EH); and EM. The responsibilities of these organizations are summarized below.

The OGC is responsible for providing legal assistance relative to implementation of the Act, preparing model cooperative agreements to be executed with states and Indian tribes, and drafting memoranda of understanding between DOE and other federal agencies when necessary.

The EH is responsible for providing occupational safety and health, environmental, and QA overview for the Project and for reviewing and approving NEPA documents. 


\section{UMTRA GROUND WATER PROJECT ORGANIZATION}

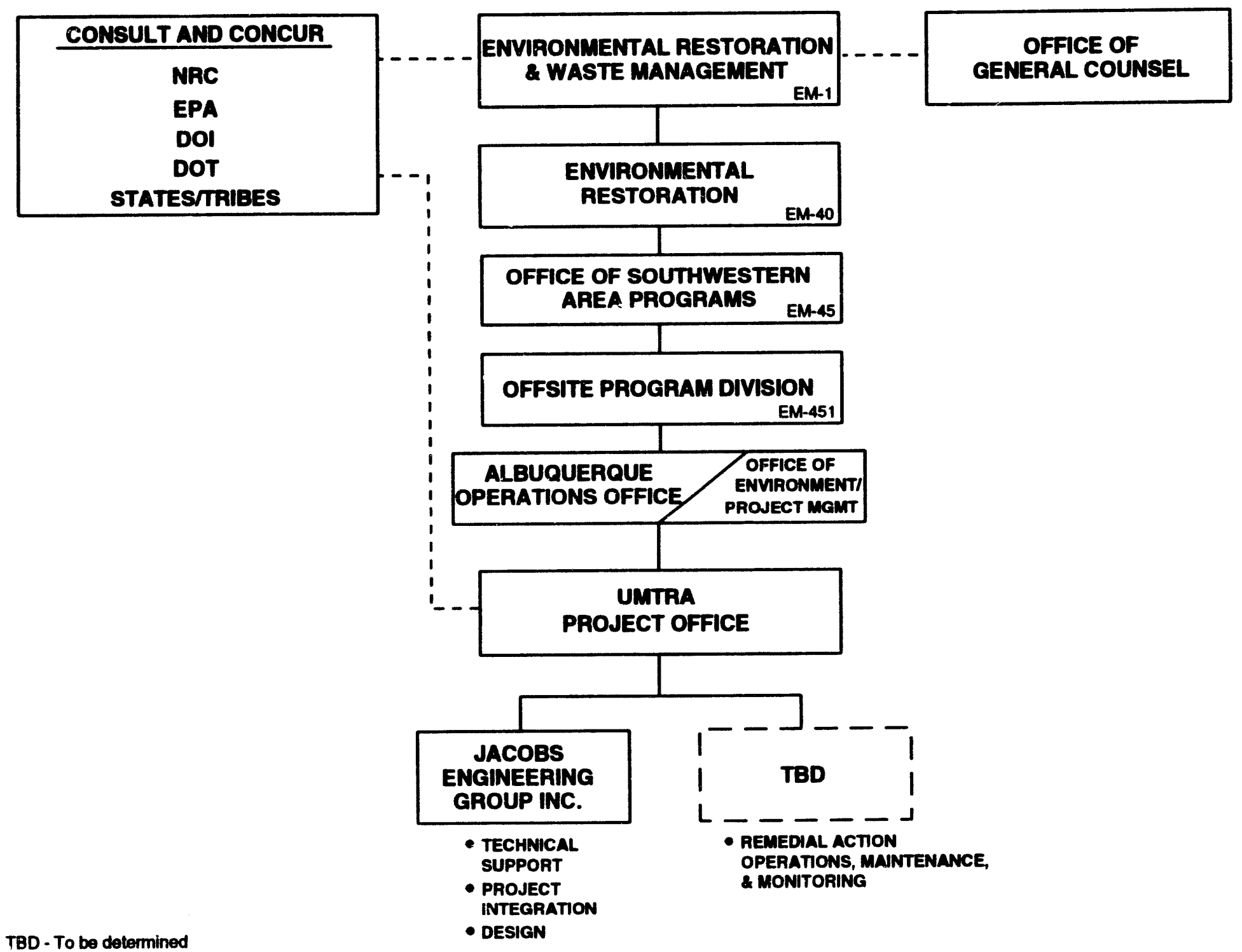


The remaining Project functions at DOE-HQ are the responsibility of EM, acting in the capacity of the PSO. EM is responsible for 1) accomplishing ground water compliance at the processing sites, 2) negotiating and executing cooperative agreements with the affected states and Indian tribes, 3) complying with NEPA requirements, and 4) developing innovative technologies for remediation.

The Act authorizes DOE to establish cooperative agreements with the affected states and Indian tribes. DOE is reviewing the cost-sharing responsibilities of the states based on remediation strategies in the Ground Water Project. The Act requires that the DOE pay 90 percent of the remedial action costs, and that the states pay the remaining 10 percent. On the four sites located on Indian lands, 100 percent of the costs for remedial action will be assumed by the federal government. The DOE is currently reviewing the appropriateness of amending the UMTRA Surface Project cooperative agreements to incorporate the requirements of the Ground Water Project or negotiating new agreements for the Ground Water Project.

\subsection{DECISION DELEGATIONS}

The Project is designated as a MP activity (MP-AL-4), with day-to-day management assigned to the $A L$. $A L$ is authorized to manage and execute Project functions within established procurement, real estate, and other operational approval thresholds. Responsibilities for AL Project management are assigned through the Office of Environment/Project Management to the Project Manager. The Project Manager is supported by the UMTRA Project Office staff, the AL matrix staff, the TAC (see Exhibit 3 and Section 5.0), and a yet to be determined Remedial Action Contractor (RAC) (see Exhibit 3 and Section 5.0). The UMTRA Project Office is responsible for managing the Project and its contractors in accordance with overall Project policy and DOE-HQ guidance.

Specifically, DOE-HO assigned responsibility for the following activities to the UMTRA Project Office:

- Coordination of activities with Indian tribes, state and local governments, and the public.

- Negotiation of cooperative agreements.

- Development of ground water compliance strategies.

- Operation of the Project Control System (PCS).

- Management of the NEPA process.

- Management of the selection and implementation of compliance strategies. 
- Initiation of procurement for and management of Project contractors.

- Acquisition of necessary licenses and permits.

- Compliance with regulations and orders.

The UMTRA Project Office is assisted in meeting these responsibilities by AL matrix support in the areas of procurement, public affairs, QA, property management, legal affairs, health and safety, environment, safeguards and security, and finance and budget.

\subsection{PROJECT CONTROL SYSTEM}

The PCS is based on the WBSs (shown in Attachment 5 and Exhibit 2) which outline and integrate all facets of Project activities. The system comprises six major elements which are summarized below and will be discussed in more detail in the Project Management Plan.

- Work definition. Ensures that all Project work is identified and defined to the WBS and is planned, scheduled, and budgeted before authorization.

- Work authorization. Provides control of the initiation of work and changes to previously authorized work.

- Work scheduling and control. Provides for establishing an approved Project master schedule; implementing milestone monitoring and updating; ensuring systematic and in-depth cost, schedule, and technical baseline impact analyses; providing systematic and consistent change control; and providing an assessment of risks to cost, schedule, critical path, milestones, and/or the technical baseline.

- Acquisition strategy. Identifies planned procurement and contracting activities (including acquisition of land or interests in land), defines the relationships and responsibilities of all Project participants, and provides for realistic contingency planning.

- Management reporting and reviews. Uses the DOE Uniform Reporting System (URS) to establish a standard procedure for collecting and integrating essential cost, manpower, schedule, and technical information for managing contractual performance.

- Change control. Ensures that change control procedures are developed and implemented for orderly control and management and that Project baseline integrity is maintained.

Project performance is measured against the three elements of the baseline: scope, cost, and schedule (discussed below and in Section 8.0) established by the UMTRA Project Office and approved for use by EM-40. The UMTRA Project 
Office uses the baseline data to develop detailed work plans for the Project and its participants.

- Scope. Develop the initial Ground Water Project requirements, the UMTRA Project Office prepared a technical baseline table (see Attachment 7). The target strategy is based upon preliminary site information. Final decisions on remedial action approach cannot be made until publication of the PEIS and record of decision. The technical baseline evolves from the EPA standards and applicable federal and state laws into the compliance strategies and engineering designs that detail necessary remedial actions that comprise the scope baseline.

- Cost. Based on the Project cost estimate summarized in this Project Plan. The UMTRA Project Office controls cost through management of the TEC and through modified application of the DOE Cost and Schedule Control Systems Criteria (CSCSC) for the TAC (and the RAC when it is identified). This control technique results in the following actions: reconciliation and agreement on the cost baseline by all Project participants, minimization of changes to the approved baseline, controlled communication among Project participants, trend analysis reporting, and the maintenance of a consistent approach to evaluating and processing changes.

- Schedule. Based on the baseline approved for use (see Section 1.1) which predicts an end date of FY2014. The scheduling system incorporates these requirements and consists of a hierarchy of schedules, critical paths, and milestones that start at the Project level and extend down to contractor schedules used for time-phasing detailed work packages (see Attachment 8).

The Project funding profile is predicated on the cost baseline and provided through annual AL-Approved Funding. The TEC includes contingency which was identified in the Project's risk analysis. Section 3.4 describes how contingency funds were estimated. Control of contingency funds rests with the Project Manager. Any changes to the Project funding baseline (see Exhibit 4) will result in corresponding changes to the other baselines in accordance with the change control procedures.

Cost and schedule thresholds for Project control are described in Section 8.0, Controlled Items/Baselines. 


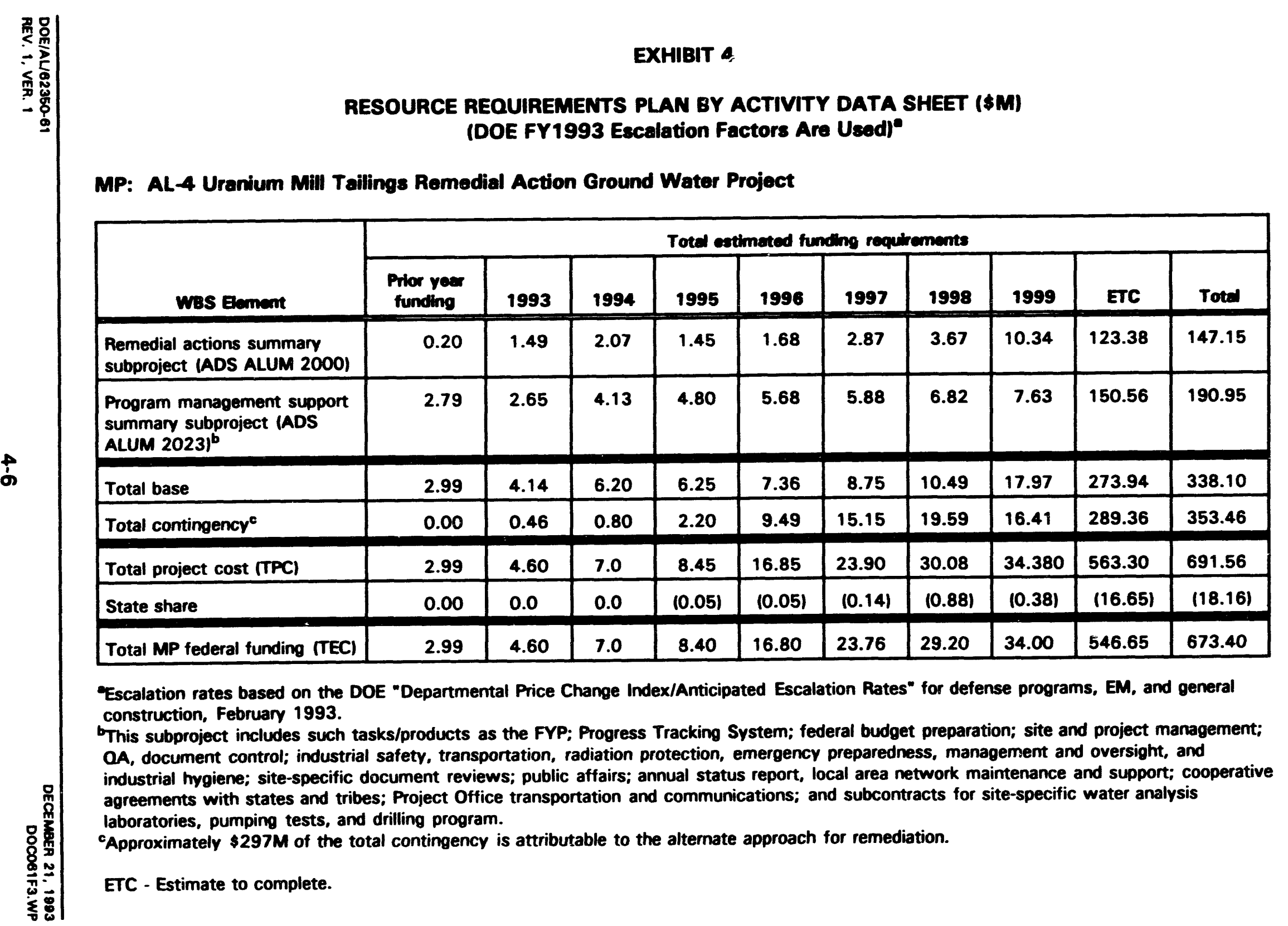




\subsection{ACQUISITION STRATEGY}

In accordance with the DOE policy, a business strategy group develops the Project acquisition strategy. The initial acquisition strategy adopted considered the overall Project environment; functional, mission-oriented requirements; and institutional interrelationships. Consideration was also given to the objectives of maximizing competition, maintaining contractual flexibility, and obtaining the optimal balance of overall coordination, integration, and management responsibility between Project participants.

Although the acquisition strategy initially developed provides for a TAC and a RAC, the UMTRA Project Office is currently supported by one major contractor, which is a TAC. Later work is identified for one or more RACs. However, at this time, no RAC has been identified. The TAC comprises the prime contractor, Jacobs Engineering Group Inc., and its subcontractors: Roy F. Weston, Inc.; Sergent, Hauskins \& Beckwith; and Geraghty and Miller, Inc.

The purpose of having a TAC and one or more RACs is to ensure an independent assessment of both TAC-prepared designs and RAC operations and maintenance. Through its planning and management support efforts, the TAC provides for overall Project integration by assisting the UMTRA Project Office in developing and implementing Projectlevel plans, budgets, and schedules. Project management authority is retained in the UMTRA Project Office along with the responsibility for Project control and overall technical management. The TAC also supports the UMTRA Project Office in all Project environmental activities and in coordinating data-gathering and site characterization efforts. The RAC would provide for on-site management of the remedial action under the direction of the UMTRA Project Office site managers who serve in a line management capacity. Because the UMTRA Project Office expects to use a regulatory approach to accomplishing ground water compliance at the processing sites, only a small effort is planned for proposed work associated with a RAC. The responsibilities of the TAC and RAC are listed below.

\section{Technical Assistance Contractor}

- Support and monitor technology development, application, and transfer.

- Gather environmental data.

- Conduct baseline risk assessments.

- Develop and implement detailed site characterization.

- Prepare programmatic regulatory compliance and NEPA documents, including the PEIS and site-specific EAs.

- Develop site compliance strategies.

- Assist in the management of environmental activities. 
- Prepare sampling and analysis plans and site RAPs.

- Prepare site conceptual designs, design specifications, and design packages.

- Prepare site observational work plans.

- Prepare site environmental monitoring reports.

- Prepare site completion reports.

- Develop and implement Project-level programs for health and safety, QA, and public participation.

- Operate the Integrated Project Management System (IPMS).

\section{Remedial Action Contractor}

- Prepare bid packages.

- Provide construction management and inspection.

- Operate active remedial action programs.

- Provide planning and management support in the areas of site health and safety. maintenance and modification plans, equipment records, and quality control.

As discussed in Section 4.1, the acquisition strategy also identifies cooperative agreements as the vehicles for DOE-state cost sharing, state/Indian tribal participation, and site acquisition. In this manner the acquisition structure is designed to provide a balanced and integrated basis for achieving the Project objectives. Attachment 9 summarizes the curient status of the acquisition strategy. 


\subsection{PROJECT SCHEDULE}

\subsection{BACKGROUND}

Project schedules consist of a hierarchy of schedules that start at the Project level and extend down to schedules used for time-phasing of detailed work by Project participants. Each of the lower tier schedules is compatible with the Project master schedule, with key milestones traceable from the top level schedule to lower tier schedules.

The Project scheduling hierarchy is as follows:

- Sites master schedule (see Attachment 8).

- Individual site schedules.

- Contractor supporting schedules.

All schedules are based upon the targeted strategies. Although concurrence has not been reached on these strategies, they have been aligned to provide for implementation of the concurred upon compliance strategy for each site and the completion of active remedial action at all sites requiring it. The major milestones for each activity through FY1999 are shown in Attachment 10.

\section{STATUS}

Since the Project was initiated in FY1991, the following Project milestones have been accomplished:

- Approval of mission need.

- Action Description Memorandum for PEIS approved by DOE-HQ.

- Notice of Intent to prepare a PEIS approved by DOE-HQ.

- PEIS proposed action plus alternatives drafted.

- Fourteen public site orientation meetings and twelve public formal scoping meetings completed in FY1993.

- PEIS Implementation Plan completed.

- Draft TAGR document completed.

- Six baseline risk assessments initiated. 


\subsection{SCHEDULE ASSUMPTIONS}

Achieving the schedule objective of completing the Project by FY2014 is contingent upon the following assumptions:

- Authorization/appropriation of funds by Congress and the states in accordance with the resource requirements plan (Exhibit 4).

- Timely review and acceptance of the proposed approach described in the PEIS by DOE-HQ, regulators, affected states and tribes, and the public.

- Timely concurrence on site-specific compliance strategies from DOE-HQ, the NRC, states, and Indian tribes.

- No deviations from the technical assumptions listed in Section 2.3. 


\subsection{RESOURCES PLAN}

\section{$7.1 \quad$ costs}

The total Project cost (TPC) is based on the proposed scope and current sites master schedule and is subject to change, if this schedule is impacted.

Exhibit 4 shows the resource requirements plan for federal and state funding associated with the site master schedule and shows the resource requirements plan by ADS. The Act does not contain funding authorization; however, it indicates that Project funds are to be included in annual authorization and appropriation acts.

\subsection{MANPOWER}

The UMTRA Project Office plans to phase UMTRA Project Office staffing within Project ceiling and funding constraints as well as to correspond to the scheduled accomplishment of the Project mission. Attachment 11 presents Project staffing estimates for key participants.

\subsection{COST ASSUMPTIONS}

Attainment of the cost objective of completing the Project within the targeted TEC is contingent upon the following assumptions:

- No deviations from the technical and schedule assumptions provided in Sections 2.3 and 6.3 , respectively.

- State payment of 10 percent of the remedial action costs.

- Validity of the DOE-prescribed escalation indices. 


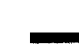$$
\text { - }
$$
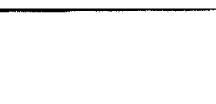


\subsection{CONTROLLED ITEMS/BASELINES}

Solected technical, cost, and schedule parameters have been established for baseline control and performance measurement. The parameters listed in Attachment 12 have been baselined through EM-40 and can be changed only through formal change control, as discussed in Section 4.0 of this Project Plan. Attachment 13 summarizes the thresholds and approval levels required to change the baseline parameters.

\begin{tabular}{ll}
\hline Control Baseline & \multicolumn{1}{c}{ Parameters } \\
\hline Scope & $\begin{array}{l}\text { Regulatory compliance strategy, contaminants, estimated } \\
\text { number of gallons of contaminated ground water, and additional } \\
\text { characterization required (see Attachment } 7 \text { as an example). }\end{array}$ \\
Cost & $\begin{array}{l}\text { Annual cost and TEC by subproject (see Exhibit 4). } \\
\text { Schedule }\end{array}$ \\
& $\begin{array}{l}\text { Major milestones by subproject to include start of site } \\
\text { assessment, completion of NEPA activities, and implementation } \\
\text { of compliance strategy (see Attachment 10). Milestones are } \\
\text { detailed through FY1999 only per guidance from EM-40. }\end{array}$ \\
\hline
\end{tabular}

The thresholds for cost and schedule performance assessment reporting are established uniformly on a site basis. Any difference between a site's planned and actual performance that exceeds \pm 15 percent or schedule slippage of 30 days shall require analysis and identification of corrective action. Notification and explanation of cost and schedule variances exceeding these thresholds shall be provided in a variance analysis which is included in the monthly Progress Tracking System report to DOE-HO. In addition to the thresholds identified for cost and schedule, significant cost, schedule, or performance objectives shall be reported to DOE-HO in the quarterly Project Manager's Progress Report. 


\subsection{SUBMISSIONS AND APPROVALS}

This UMTRA Project Plan is submitted by:

Albert R. Chernoff

Date

Project Manager

Date

Bruce G. Twining

Manager, Albuquerque Field Office

Ralph Lightner

Director, Office of Southwestern Area Programs

Date

R. P. Whitfield

Date

Deputy Assistant Secretary

Office of Environmental Restoration

The plan identifies the mission and objectives of the Project, outlines the technical and managerial approach for achieving them, and summarizes the technical scope, cost, and schedule baselines that have been established to guide operational activity. Approval will be required by the PSO if the scope of the Project changes, or if the TEC increases by $\$ 30 \mathrm{M}$, or if the schedule slips by 6 months.

\section{Approved:}

Thomas Grumbly, Assistant Secretary

Date

for Environmental Restoration and Waste Management 


\subsection{REFERENCES}

DOE (U.S. Department of Energy), 1993a. Technical Approach to Ground Water Restoration, draft, prepared by the U.S. Department of Energy, UMTRA Project Office, Albuquerque Operations Office, Albuquerque, New Mexico.

DOE (U.S. Department of Energy), 1993b. Uranium Mill Tailings Remedial Action Fiscal Year 1992 Roadmap, UMTRA-DOE/AL-400135.0000, prepared by the U.S. Department of Energy, UMTRA Project Office, Albuquerque Operations Office, Albuquerque, New Mexico.

NRC (U.S. Nuclear Regulatory Commission), 1989. "Standard Format and Content for Documentation of Remedial Action Selection at Title I Uranium Mill Tailings Sites," staff technical position, Division of Low-Level Waste Management and Decommissioning, Office of Nuclear Material Safety and Safeguards, February 24, 1989, Washington, D.C.

\section{CODE OF FEDERAL REGULATIONS}

40 CFR Part 192, "Health and Environmental Protection Standards for Uranium and Thorium Mill Tailings," U.S. Environmental Protection Agency (1988).

40 CFR \$ \$1500-1508, "Regulations for Implementing the Procedural Provisions of the National Environmental Policy Act," Council on Environmental Quality (1978).

\section{DOE ORDERS}

Order 5400.1, General Environmental Protection Program, June 29, 1990, U.S. Department of Energy, Environmental Protection Division, Office of Environment, Safety and Health, Washington, D.C.

\section{PUBLIC LAW}

PL 100-616 (Public Law 100-616), 1988. Amendment to PL 95-604, Uranium Mill Tailings Remedial Action Amendments of 1988, November 15, 1988, 100th Congress of the United States of America, Washington, D.C.

\section{UNITED STATES CODES}

42 USC $\$ 2011$ et seq., Atomic Energy Act, 1954.

42 USC $\$ 4321$ et seq. . National Environmental Policy Act, January 1, 1970.

42 USC $\$ 7901$ et seq., Uranium Mill Tailings Radiation Control Act of 1978, November 8, 1978. 
UMTRA GROUND WATER PROJECT PLAN

ATTACHMENTS

1 
TABLE OF CONTENTS

Attechment

Pane

1 Summary of Proposed EPA Ground Water Standards . . . . . . . . . . . A-1

2 UMTRA Ground Water Project Flow Chart $\ldots \ldots \ldots \ldots \ldots \ldots \ldots \ldots$

3 UMTRA Ground Water Project Logic Diagram . . . . . . . . . . . . . A-3

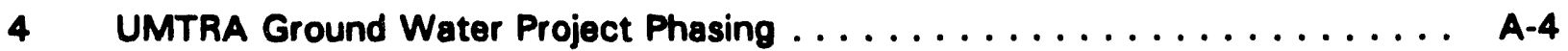

5 UMTRA Ground Water Project Work Breakdown Structure . . . . . . . . . . A-6

6 UMTRA Ground Water Project Baseline Risk Matrix . . . . . . . . . . . . A-7

7 UMTRA Ground Water Project Scope Baseline $\ldots \ldots \ldots \ldots \ldots \ldots$. . . . . A

8 UMTRA Ground Water Remediation Project Sites Schedule . . . . . . . . A-12

9 UMTRA Ground Water Project Acquisition Structure . . . . . . . . . A-13

10 UMTRA Ground Water Project Headquarters Monitored Milestones from $9 / 92$ to $9 / 99 \ldots \ldots \ldots \ldots \ldots \ldots \ldots$. . . . . . . . . . . . . . . . . .

11 UMTRA Ground Water Project Staffing $\ldots \ldots \ldots \ldots \ldots \ldots \ldots \ldots$

12 Summary of UMTRA Ground Water Project Baseline Information . . . . . A-17

13 Summary of UMTRA Ground Water Project Thresholds . . . . . . . . . A-18 


\begin{tabular}{|l|l|}
\hline \multicolumn{1}{|c|}{$\begin{array}{c}\text { Ground water compliance at } \\
\text { processing sites }\end{array}$} & \multicolumn{1}{c|}{ Proposed standard } \\
\hline $\begin{array}{l}\text { Identify hazardous constituents in } \\
\text { down gradient ground water }\end{array}$ & $\begin{array}{l}\text { Shall either meet background or MCLs for listed hazardous constituents or } \\
- \text { Seek and justify alternate concentration limits. } \\
- \text { Obtain supplemental standards. }\end{array}$ \\
\hline Monitoring program & $\begin{array}{l}\text { Shall be adequate to monitor compliance with ground water cleanup } \\
\text { standards. }\end{array}$ \\
\hline Implementation & $\begin{array}{l}\text { Characterization program shall be sufficient to establish background ground } \\
\text { water quality, extent of ground water contamination, and baseline risk. } \\
\text { Remedial action plans should include schedule and steps necessary to } \\
\text { complete the cleanup of ground water; should specify details of methods for } \\
\text { ground water compliance. } \\
\text { May apply supplemental standards in lieu of MCLs to individual situations if } \\
\text { eligibility requirements of } 40 \text { CFR } 192 \text { are met. } \\
\text { Verification monitoring to ensure full compliance with proposed ground water } \\
\text { standards. }\end{array}$ \\
\hline
\end{tabular}




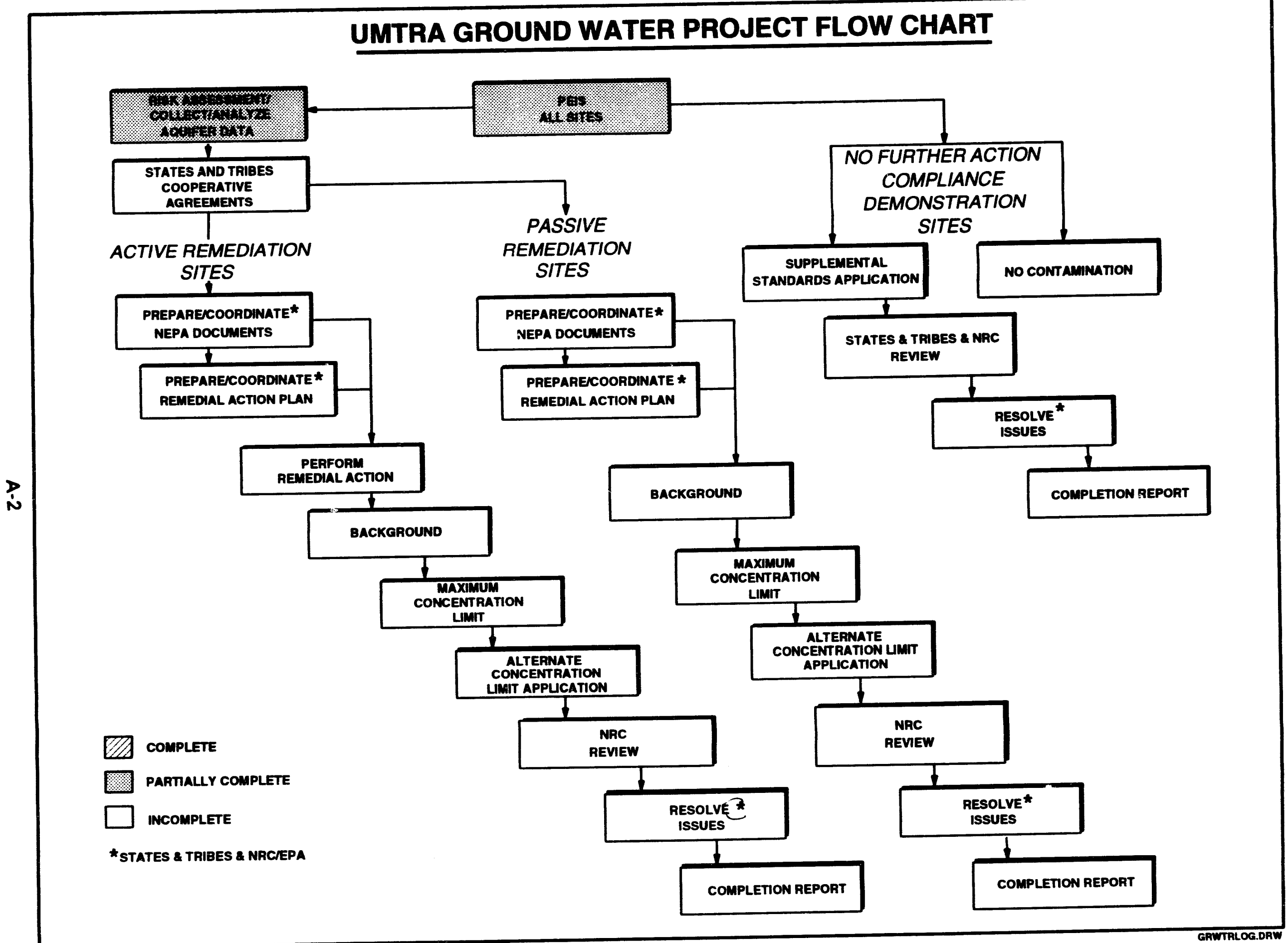




\section{UMTRA GROUND WATER PROJECT LOGIC DIAGRAM}

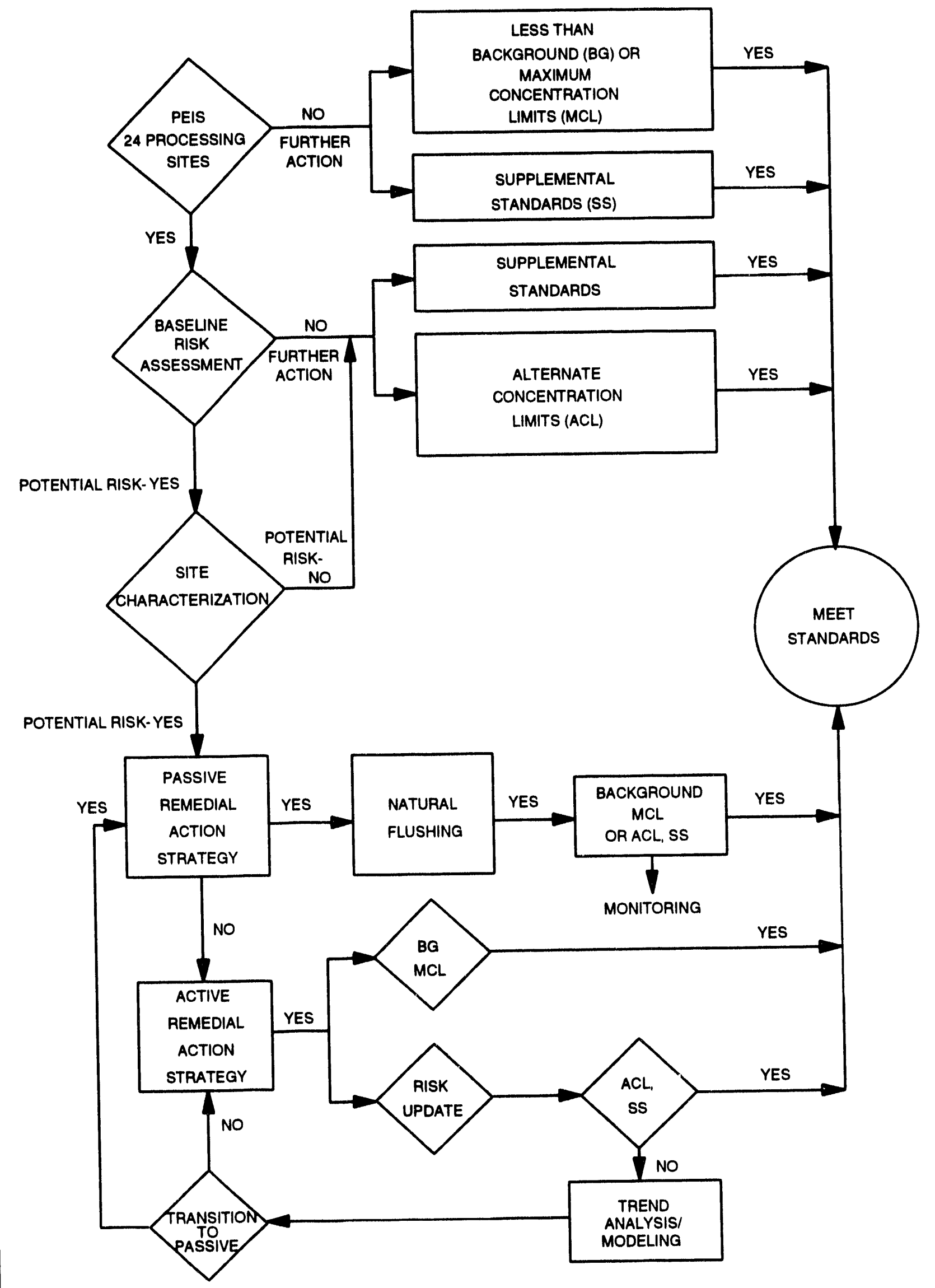




\begin{tabular}{|c|c|c|c|c|c|}
\hline 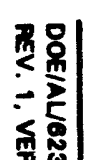 & & UMTRA GI & $\begin{array}{c}\text { ATTACHMENT } 4 \\
\text { OUND WATER PROJEC }\end{array}$ & PHASING & \\
\hline 9 & Project phese & Activity & Description & Product & Dectalon \\
\hline & NEPA process & $\begin{array}{l}\text { Conduct environmental } \\
\text { assessment and develop } \\
\text { remedial action options. }\end{array}$ & $\begin{array}{l}\text { Perform field data } \\
\text { collection, analysis, } \\
\text { modeling, and baseline } \\
\text { risk assessments. } \\
\text { Develop and evaluate } \\
\text { options for remedial } \\
\text { action based on } \\
\text { analysis. } \\
\end{array}$ & $\begin{array}{l}\text { Programmatic EIS and } \\
\text { site-specific } \\
\text { onvironmental } \\
\text { assessments/FONSIs. }\end{array}$ & $\begin{array}{l}\text { Compliance alternatives } \\
\text { assessment. }\end{array}$ \\
\hline & Site acquisition & $\begin{array}{l}\text { Acquire monitor well } \\
\text { agreements and any } \\
\text { other agreoments } \\
\text { deemed to be necessary } \\
\text { for land access and } \\
\text { water rights. }\end{array}$ & $\begin{array}{l}\text { Negotiate monitor well } \\
\text { agreements and prepare } \\
\text { MOUs for federal land } \\
\text { access. Acquire water } \\
\text { rights. }\end{array}$ & $\begin{array}{l}\text { Land access agreements } \\
\text { and water rights. }\end{array}$ & $\begin{array}{l}\text { Acquire monitor well } \\
\text { access and water rights } \\
\text { to support detailed site } \\
\text { characterization and } \\
\text { access for active } \\
\text { remediation or natural } \\
\text { flushing. }\end{array}$ \\
\hline & $\begin{array}{l}\text { Remedial action } \\
\text { planning }\end{array}$ & $\begin{array}{l}\text { Perform remedial action } \\
\text { planning and design } \\
\text { development. }\end{array}$ & $\begin{array}{l}\text { Prepare a detailed site } \\
\text { plan for remedial action. }\end{array}$ & $\begin{array}{l}\text { Site observational work } \\
\text { plan and draft RAP. }\end{array}$ & $\begin{array}{l}\text { Ensure that the RAP } \\
\text { moets EPA standards } \\
\text { and requirements. } \\
\text { Proceed with } \\
\text { engineering } \\
\text { development. }\end{array}$ \\
\hline & $\begin{array}{l}\text { Remodial action design } \\
\text { and evaluation }\end{array}$ & $\begin{array}{l}\text { Perform detail } \\
\text { engineoring. }\end{array}$ & $\begin{array}{l}\text { Prepare drawings, } \\
\text { specifications, cost } \\
\text { estimate, and schedule; } \\
\text { finalize RAP. } \\
\end{array}$ & Final RAP/final design. & $\begin{array}{l}\text { Proceed into remedial } \\
\text { operations (oxtract and } \\
\text { land application and/or } \\
\text { natural flushing). }\end{array}$ \\
\hline 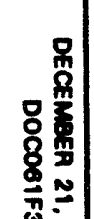 & Remedial action & $\begin{array}{l}\text { Conduct remedial } \\
\text { operations. }\end{array}$ & $\begin{array}{l}\text { Imploment remedial } \\
\text { actions outlined in the } \\
\text { RAP, construction } \\
\text { management, field } \\
\text { services. }\end{array}$ & $\begin{array}{l}\text { Ground water } \\
\text { compliance and site } \\
\text { completion report. }\end{array}$ & $\begin{array}{l}\text { Compliance with EPA } \\
\text { standards. }\end{array}$ \\
\hline
\end{tabular}




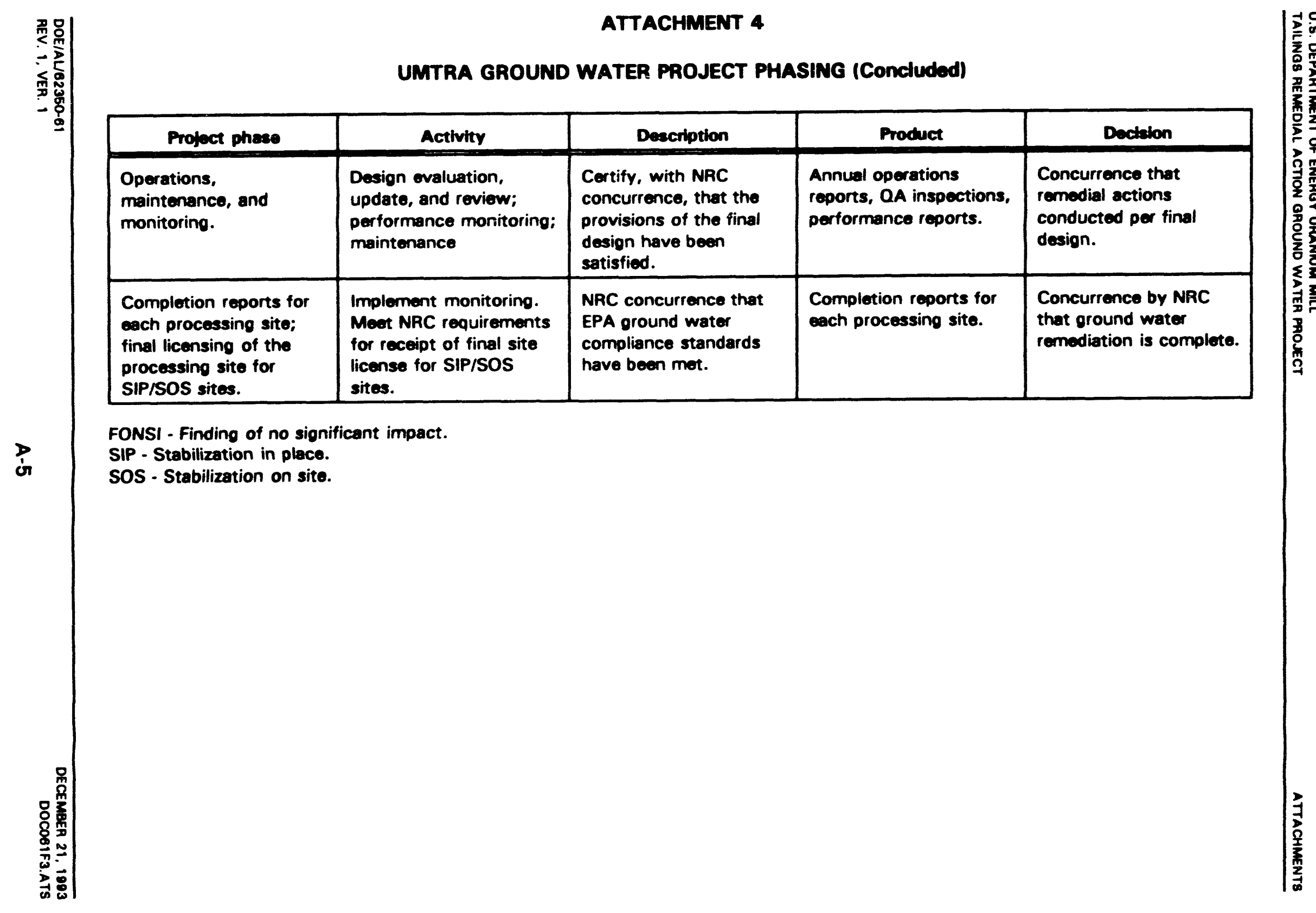




\section{UMTRA GROUND WATER PROJECT WORK BREAKDOWN STRUCTURE}

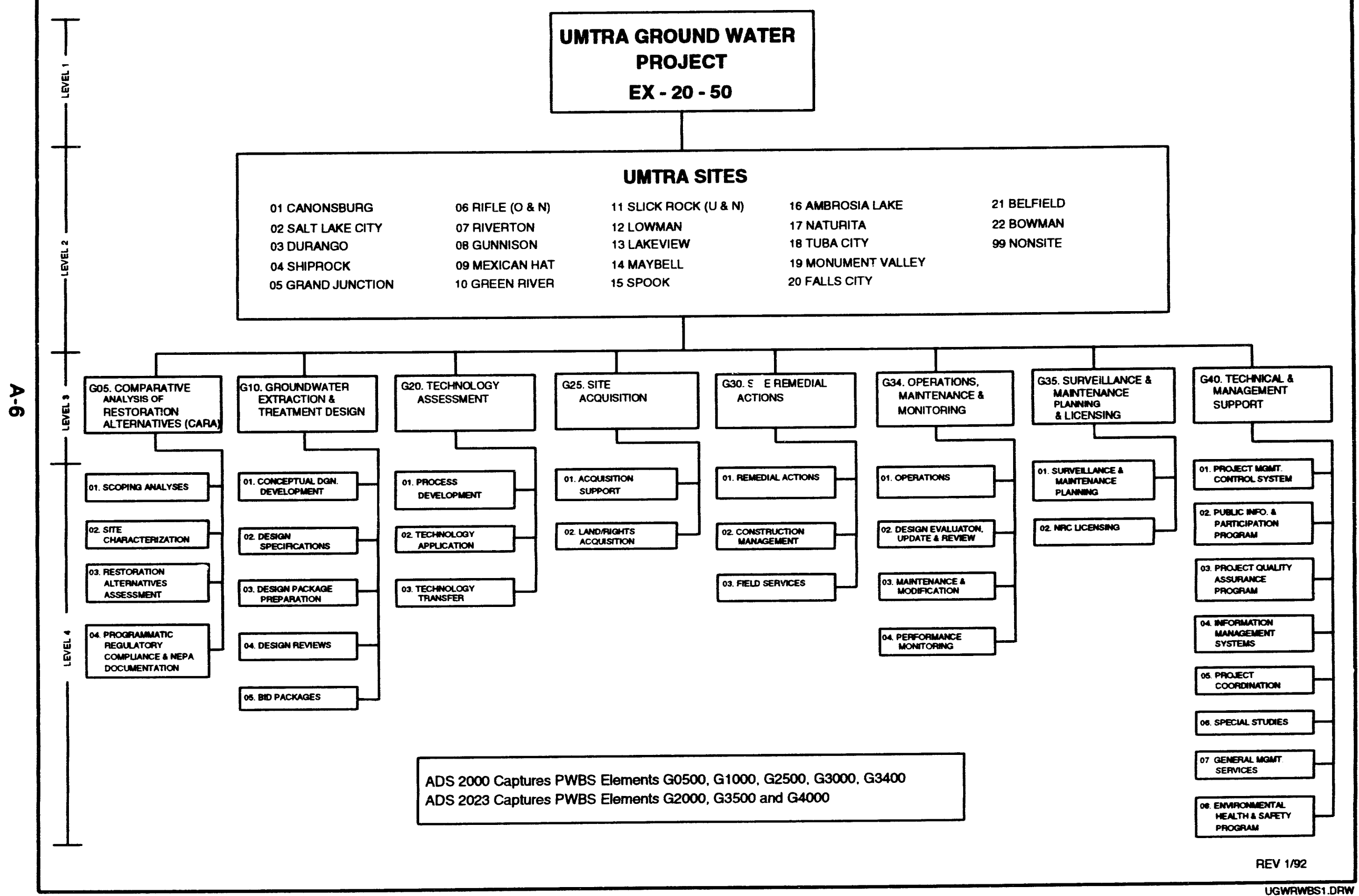




\begin{tabular}{|c|c|c|c|c|c|}
\hline \multirow{2}{*}{ 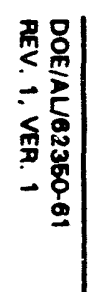 } & \multicolumn{5}{|c|}{$\begin{array}{c}\text { ATTACHMENT } 6 \\
\text { UMTRA GROUND WATER PROJECT BASELINE RISK MATRIX }\end{array}$} \\
\hline & \multirow[b]{2}{*}{ Major ritsk areas } & \multicolumn{3}{|c|}{ Rating } & \multirow[b]{2}{*}{ Rationale for risk rathe } \\
\hline & & High & Medium & Low & \\
\hline & $\begin{array}{l}\text { Public and state/tribal } \\
\text { acceptance }\end{array}$ & $x$ & & & $\begin{array}{l}\text { Risk is considered HIGH since targeted compliance strategies could be } \\
\text { rejected by the local citizens in favor of more costly and technically } \\
\text { unnecessary alternate approaches. However, the Project has and will } \\
\text { continue to keep citizens apprised of all aspects of the Project via } \\
\text { public meetings. Additionally, when published, the PEIS will present } \\
\text { the site-specific data supporting the Project's position on the preferred } \\
\text { approaches. }\end{array}$ \\
\hline & Regulatory impacts & & $x$ & & $\begin{array}{l}\text { Risk is considered MEDIUM. Although the possibility of changes to the } \\
\text { proposed EPA ground water standards is considered to be low, the } \\
\text { possibility of new or more stringent state or tribal compliance } \\
\text { regulations is considered to be medium for some sites. Changes prior } \\
\text { to or following completion of the PEIS would cause major perturbations } \\
\text { to the Project's costs and schedule. Impact could be very high. }\end{array}$ \\
\hline & Multiple participants & & $x$ & & $\begin{array}{l}\text { Potential schedule delays as a result of the number of participants } \\
\text { required to approve NEPA documentation. Risk is considered MEDIUM } \\
\text { since experience acquired on UMTRA Surface Project provides } \\
\text { knowledge about working with NRC, states and tribes, and the general } \\
\text { public. }\end{array}$ \\
\hline & State funding & & $x$ & & $\begin{array}{l}\text { Risk is considered MEDIUM. The state sharing arrangement for the } \\
\text { Ground Water Project has not yet been determined. Additionally, at } \\
\text { such time that the arrangement has been agreed upon by the DOE and } \\
\text { the states, there is risk that the states will not have funding available } \\
\text { when it is required. }\end{array}$ \\
\hline 吊 & $\begin{array}{l}\text { Federal funding } \\
\text { perturbations }\end{array}$ & & $x$ & & $\begin{array}{l}\text { Risk is considered MEDIUM. Extensive experience on the UMTRA } \\
\text { Surface Project indicates that federal planning levels are not always } \\
\text { attained because of Congressional or internal reductions. }\end{array}$ \\
\hline
\end{tabular}




\begin{tabular}{|c|c|c|c|c|c|}
\hline \multirow{3}{*}{\multicolumn{2}{|c|}{ 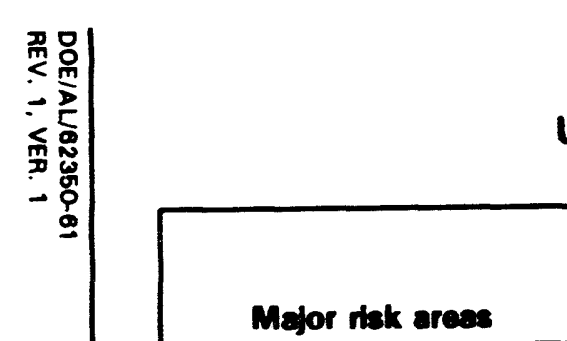 }} & \multicolumn{4}{|c|}{$\begin{array}{l}\text { ATTACHMENT } 6 \\
\text { UTRA GROUND WATER PROJECT BASELINE RISK MATRIX (Concluded) }\end{array}$} \\
\hline & & \multicolumn{3}{|c|}{ Rating } & \multirow[b]{2}{*}{ Rationale for risk reting } \\
\hline & & High & Medium & Low & \\
\hline \multirow{4}{*}{ סे } & Land access & & $x$ & & $\begin{array}{l}\text { Risk is considered MEDIUM since all is not known at this time regarding } \\
\text { how extensive land access requirements will be. Access to wells is } \\
\text { imperative for the detailed characterization phase. It is possible that } \\
\text { the state and Indian tribes will require that cooperative agreements be } \\
\text { in place for the Ground Water Project prior to allowing access for } \\
\text { characterization. Existing cooperative agreements for the Surface } \\
\text { Project are expected to be updated to accommodate the Ground Water } \\
\text { Project rather than develop new, separate agreements for the Ground } \\
\text { Water Project. However, at this time, the agreements have not yet } \\
\text { been modified. }\end{array}$ \\
\hline & $\begin{array}{l}\text { Plume size/ } \\
\text { concentration of } \\
\text { contaminants }\end{array}$ & & & $x$ & $\begin{array}{l}\text { The risk is considered LOW for encountering higher contaminant } \\
\text { concentrations and/or additional plume contaminants. }\end{array}$ \\
\hline & Safety & & & $\mathbf{x}$ & $\begin{array}{l}\text { While the construction industry has a high accident rate, the practices } \\
\text { used for the UMTRA Surface Project have reduced the potential for } \\
\text { accidents by going beyond the OSHA requirements. In addition, the } \\
\text { targeted remediation strategies include only two active remediation } \\
\text { sites. For these two reasons, the safety risk is considered to be LOW. }\end{array}$ \\
\hline & Technical requirements & & & $\mathbf{x}$ & $\begin{array}{l}\text { The risk is considered LOW because technology to meet current EPA } \\
\text { standards is available. Additionally, there is minimal risk that a new } \\
\text { technology would be developed that would cause the EPA to change } \\
\text { its standards or regulations for cleanup. }\end{array}$ \\
\hline \multirow{2}{*}{ 员 } & Cost & $\mathbf{x}$ & & & $\begin{array}{l}\text { The risk is considered HIGH at this early stage of the Project. Cost } \\
\text { increases are possible due to above risks. }\end{array}$ \\
\hline & Schedule & $\mathbf{x}$ & & & $\begin{array}{l}\text { Risk is considered HIGH for reasons stated above and staffing } \\
\text { constraints. }\end{array}$ \\
\hline
\end{tabular}




\begin{tabular}{|c|c|c|c|c|c|}
\hline \multirow{2}{*}{ 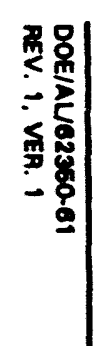 } & \multicolumn{5}{|c|}{$\begin{array}{c}\text { ATTACHMENT } 7 \\
\text { UMTRA GROUND WATER PROJECT SCOPE BASEUNE }\end{array}$} \\
\hline & Ste location & $\begin{array}{l}\text { rarget } \\
\text { remediotion } \\
\text { strategy }\end{array}$ & Contaninants & $\begin{array}{l}\text { Eetimexed mumber of gelloss } \\
\text { conteninened }\end{array}$ & 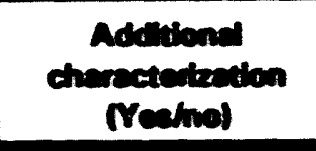 \\
\hline \multirow{6}{*}{$\dot{0}$} & Ambrosia Lake, NM & $\begin{array}{l}\text { No further action } \\
\text { compliance } \\
\text { demonstration. }\end{array}$ & $\begin{array}{l}\text { Not applicable as milling } \\
\text { activities created shallow squifer. }\end{array}$ & $\begin{array}{l}\text { Not assessed -supplemental } \\
\text { standards llimited usel. }\end{array}$ & No. \\
\hline & Belfiedd, ND & $\begin{array}{l}\text { Passive } \\
\text { remodiation. }\end{array}$ & $\begin{array}{l}\text { Concentrations of molybdenum, } \\
\text { uranium, and vanadium in ground } \\
\text { water exceed MCLs and } \\
\text { background - limited extent } \\
\text { (relatively low concentrations in } \\
\text { scattered monitor wells). }\end{array}$ & Not applicable. & Yes, monitor walls. \\
\hline & Bowman, ND & $\begin{array}{l}\text { No further action } \\
\text { compliance } \\
\text { demonstration. }\end{array}$ & $\begin{array}{l}\text { Concentrations of molybdenum } \\
\text { and uranium in ground water } \\
\text { exceed MCLs - limited extent } \\
\text { (restricted to monitor well 517). }\end{array}$ & Not applicable. & No. \\
\hline & Canonsburg, PA & $\begin{array}{l}\text { No further action } \\
\text { compliance } \\
\text { demonstration. }\end{array}$ & $\begin{array}{l}\text { Concentrations of uranium in } \\
\text { oround water exceed the MCLs - } \\
\text { limited extent (restricted to } \\
\text { monitor wolls } 413 \text { and } 506 \text { ). }\end{array}$ & Not applicable. & No. \\
\hline & Durango, CO & $\begin{array}{l}\text { Passive } \\
\text { remediation. }\end{array}$ & Uranium, selenium. & $260,000,000$ & Yes, monitor mells. \\
\hline & Falls City, TX & $\begin{array}{l}\text { No further action } \\
\text { compliance } \\
\text { demonstration. }\end{array}$ & Uranium, molybdenum. & Not assessed. & Yes, monitor walls. \\
\hline \multirow{2}{*}{ 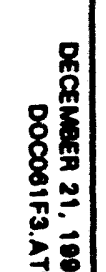 } & Grand Junction, CO & $\begin{array}{l}\text { Passive } \\
\text { remediation. }\end{array}$ & Uranium, molybdenum. & $600,000,000$ & Yes, monitor mells. \\
\hline & Green River, UT & $\begin{array}{l}\text { No further action } \\
\text { compliance } \\
\text { demonstration. }\end{array}$ & $\begin{array}{l}\text { Nitrate, selenium, molyboenum, } \\
\text { uranium. }\end{array}$ & $120,000,000$ & Yes, monitor wells. \\
\hline
\end{tabular}




\begin{tabular}{|c|c|c|c|c|c|}
\hline \multirow{2}{*}{ 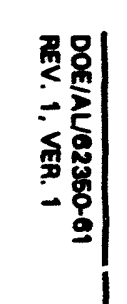 } & \multicolumn{5}{|c|}{$\begin{array}{c}\text { ATTACHMENT } 7 \\
\text { UMTRA GROUND WATER PROJECT SCOPE BASELNE (Continuad }\end{array}$} \\
\hline & sine becation & $\begin{array}{l}\text { Target } \\
\text { remodiotion } \\
\text { strategy }\end{array}$ & Contembents & $\begin{array}{l}\text { Extinneted mumber of gellons } \\
\text { contemineted }\end{array}$ & 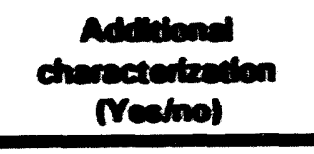 \\
\hline \multirow{8}{*}{$\stackrel{?}{\overrightarrow{0}}$} & Gunnison, co & $\begin{array}{l}\text { Passive } \\
\text { remediation. }\end{array}$ & Uranium, nickd, cadmium. & $98,000,000$ & Yes, monitor wells. \\
\hline & Lakeview, OR & $\begin{array}{l}\text { Combination or } \\
\text { passivelactive. }\end{array}$ & $\begin{array}{l}\text { Selenium, arsenic, molybdenum, } \\
\text { antimony, cadmium. }\end{array}$ & $727,000,000$ & Yes, monitor walls. \\
\hline & Lowman, 10 & $\begin{array}{l}\text { No further action } \\
\text { compliance } \\
\text { demonstration. }\end{array}$ & Not applicable. & Not applicable. & No. \\
\hline & Maybell, CO & $\begin{array}{l}\text { No further action } \\
\text { compliance } \\
\text { demonstration. }\end{array}$ & Uranium, nitrate. & Not assevesed. & No. \\
\hline & Mexican Het, UT & $\begin{array}{l}\text { No further action } \\
\text { compliance } \\
\text { demonstration. }\end{array}$ & Not applicable. & Not assessed. & No. \\
\hline & Monument Valley, AZ & $\begin{array}{l}\text { Active } \\
\text { remediation. }\end{array}$ & Nitrate. & $750,000,000$ & Yes, monitor mells. \\
\hline & Neturita, CO & $\begin{array}{l}\text { Passive } \\
\text { remodiation. }\end{array}$ & Uranium, vanadium. & $83,000,000$ & Yes, monitor wolls. \\
\hline & Rifle, CO & $\begin{array}{l}\text { Pessive } \\
\text { remediation. }\end{array}$ & $\begin{array}{l}\text { Old - uranium. } \\
\text { Now - uranium, mohybdenum, } \\
\text { cadmium, selenium, vanadium, } \\
\text { net gross alpha, nitrate. }\end{array}$ & $\begin{array}{l}\text { Old - } 34,000,000 \\
\text { Now - } 650,000,000\end{array}$ & Yes, moniter wells. \\
\hline 品 & Riverton, Wr & $\begin{array}{l}\text { Passive } \\
\text { remediation. }\end{array}$ & Uranium, molybdenum, nickel. & $230,000,000$ & Yes, monitor wells. \\
\hline
\end{tabular}




\begin{tabular}{|c|c|c|c|c|}
\hline \multirow{2}{*}{ 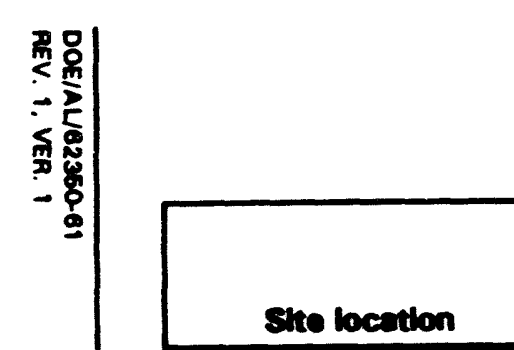 } & \multicolumn{3}{|c|}{$\begin{array}{l}\text { ATTACHMENT } 7 \\
\text { UMTRA GROUND WATER PROJECT SCOPE BASELINE (Concludad) }\end{array}$} & \multirow[b]{2}{*}{$\begin{array}{l}\text { Adidiond } \\
\text { charectedization } \\
\text { Meahno) }\end{array}$} \\
\hline & $\begin{array}{l}\text { Target } \\
\text { remodiation } \\
\text { strategy }\end{array}$ & Conteminants & $\begin{array}{l}\text { Eetimated number of gallons } \\
\text { contaminated }\end{array}$ & \\
\hline Salt Lake City, UT & $\begin{array}{l}\text { No further action } \\
\text { compliance } \\
\text { demonstration. }\end{array}$ & Uranium, molybdenum. & $700,000,000$ & Yes, monitor wells. \\
\hline Shiprock, NM & $\begin{array}{l}\text { Combination or } \\
\text { passive/active. }\end{array}$ & $\begin{array}{l}\text { Chromium, selenium, uranium, } \\
\text { molybdenum, nitrate, vanadium. }\end{array}$ & $260,000,000$ & Yes, monitor wells. \\
\hline Slick Rock, CO & \begin{tabular}{|l|} 
Passive \\
remodiation.
\end{tabular} & $\begin{array}{l}\text { NC - uranium. } \\
\text { UC - molybdenum. }\end{array}$ & $\begin{array}{l}\text { NC - } 2,300,000 \\
\text { UC - } 4,500,000 \\
\end{array}$ & Yes, monitor wells. \\
\hline Spook, Wr & $\begin{array}{l}\text { No further action } \\
\text { Compliance } \\
\text { demonstration. }\end{array}$ & Class III uppermost aquifer. & $\begin{array}{l}\text { Not assessed - supplemental } \\
\text { standards. }\end{array}$ & No. \\
\hline Tubs City, AZ & $\begin{array}{l}\text { Active } \\
\text { remediation. }\end{array}$ & Nitrate. & $170,000,000$ & Yes, monitor wolls. \\
\hline
\end{tabular}

NOTE: Tube City is the only site currently included in the performance baseline; all other sites will be included in the forecast baseline in accordance with the final PEIS.

NC - North Continent site.

UC - Union Carbide site. 


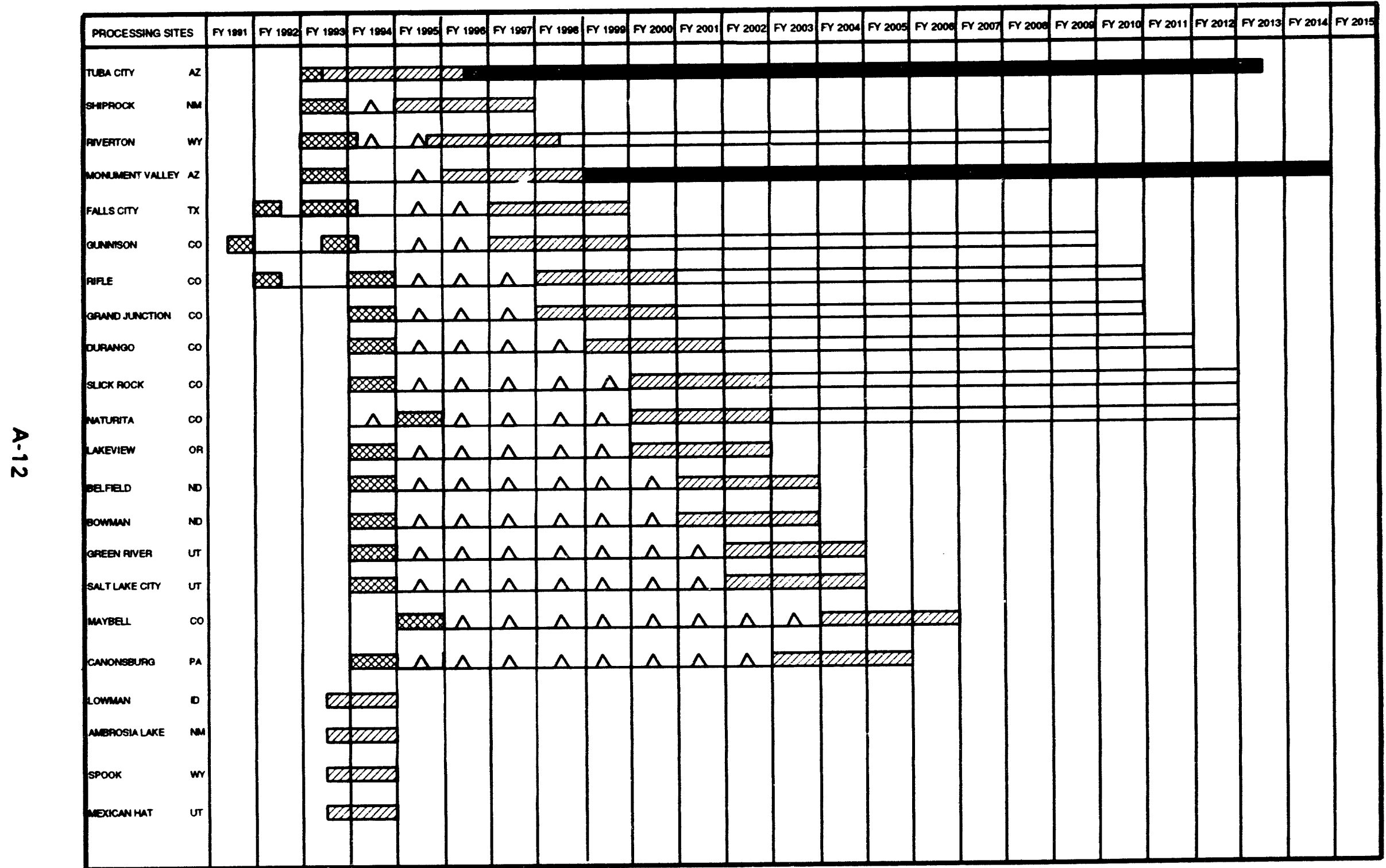




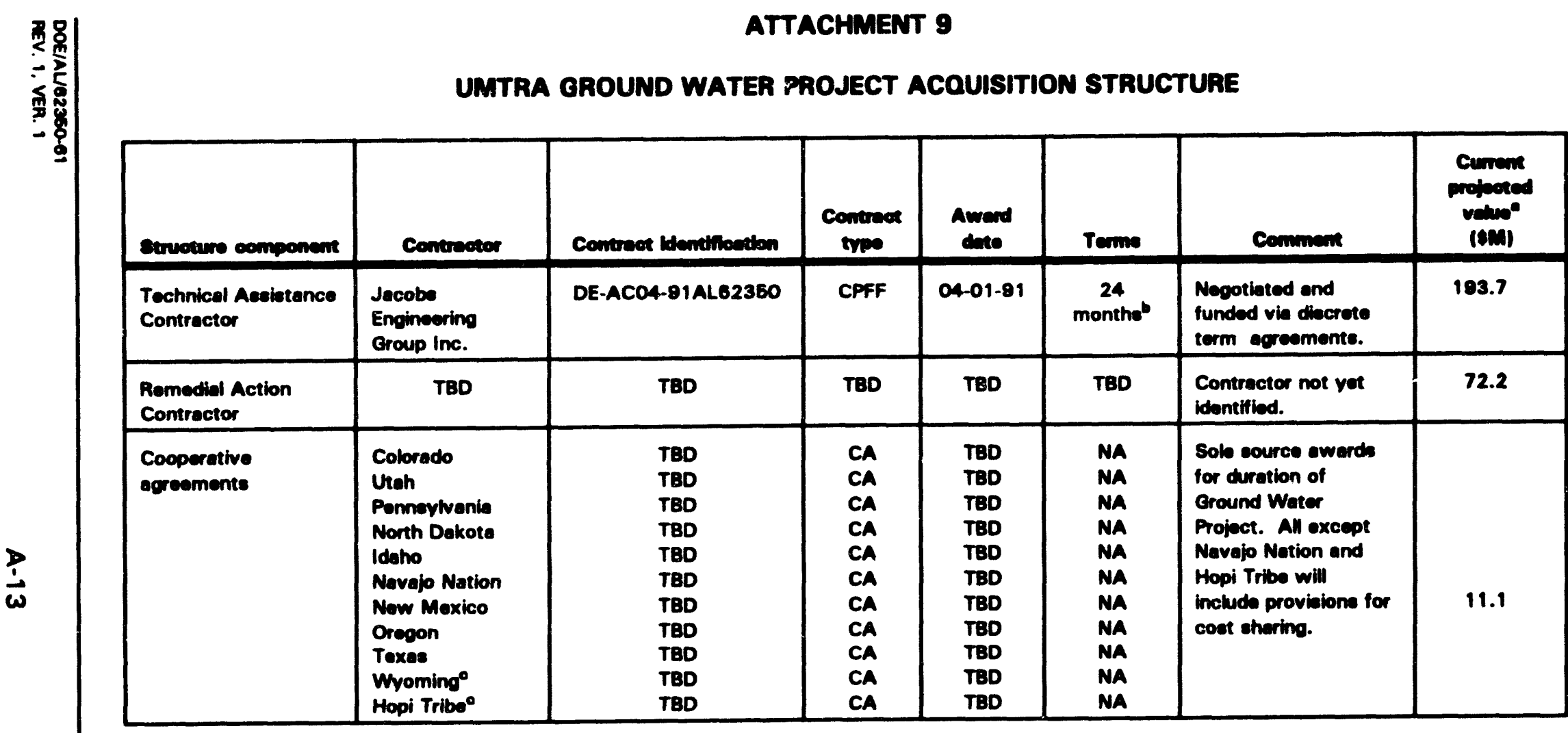

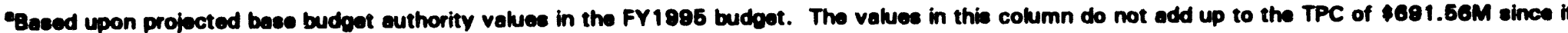
does not inchude contingoncy, reol estote, or Project Office program support.

With three 12-month options.

opotential to be multiperty egreements due to land iseues.

CA - Cooperative egreoment.

CPFF - Cost phus fixed fee.

NA - Not applicabte.

TBD - To be dotermined. 
ATTACHMENT 10

UMTRA GROUND WATER PROJECT

HEADQUARTERS MONITORED MILESTONES FROM $9 / 92$ to $9 / 99^{\circ}$

\begin{tabular}{|c|c|c|}
\hline Site & Milestone & $\begin{array}{l}\text { Baseline or } \\
\text { forecast dates }\end{array}$ \\
\hline Not applicable & $\begin{array}{l}\text { Receive approval of Mission Need } \\
\text { Receive approval of Notice of Intent from EH } \\
\text { Complete six draft baseline risk assessments } \\
\text { Complete draft PEIS } \\
\text { Complete } 12 \text { baseline risk assessments } \\
\text { Complete final PEIS and publish record of decision } \\
\text { Complete two baseline risk assessments }\end{array}$ & $\begin{array}{c}09 / 30 / 92 \text { A } \\
10 / 31 / 92 \text { A } \\
12 / 31 / 93 \\
09 / 30 / 93 \\
09 / 30 / 94 \\
09 / 30 / 94 \\
09 / 30 / 95\end{array}$ \\
\hline First site & $\begin{array}{l}\text { Initiate site assessment at first site } \\
\text { Submit site observational work plan (SOWP) to NRC } \\
\text { and states/tribes at first site } \\
\text { Receive approval from NRC on SOWP at first site } \\
\text { Publish FONSI/EA at first site } \\
\text { Submit final RAP to NRC at first site } \\
\text { Receive NRC concurrence on final RAP at first site } \\
\text { Implement compliance strategy at first site }\end{array}$ & $\begin{array}{l}04 / 01 / 93 \text { A } \\
12 / 31 / 93 \\
03 / 31 / 94 \\
03 / 31 / 95 \\
03 / 31 / 96 \\
06 / 30 / 96 \\
07 / 01 / 96 \\
\end{array}$ \\
\hline Second site & $\begin{array}{l}\text { Initiate site assessment at second site } \\
\text { Submit SOWP to NRC and states/tribes at second site } \\
\text { Receive approval from NRC on SOWP at second site } \\
\text { Publish FONSI/EA at second site } \\
\text { Submit final RAP to NRC at second site } \\
\text { Receive NRC concurrence on final RAP at second site } \\
\text { Implement compliance strategy at second site }\end{array}$ & $\begin{array}{l}10 / 01 / 94 \\
12 / 31 / 94 \\
03 / 31 / 95 \\
09 / 30 / 97 \\
09 / 30 / 98 \\
12 / 31 / 98 \\
01 / 01 / 99\end{array}$ \\
\hline Third site & $\begin{array}{l}\text { Initiate site assessment at third site } \\
\text { Submit SOWP to NRC and states/tribes at third site } \\
\text { Receive approval from NRC on SOWP at third site } \\
\text { Publish FONSI/EA at third site } \\
\text { Submit final RAP to NRC at third site } \\
\text { Receive NRC concurrence on final RAP at third site } \\
\text { implement compliance strategy at third site }\end{array}$ & $\begin{array}{l}04 / 01 / 95 \\
06 / 30 / 95 \\
09 / 30 / 95 \\
03 / 31 / 98 \\
03 / 31 / 99 \\
06 / 30 / 99 \\
07 / 01 / 99 \\
\end{array}$ \\
\hline
\end{tabular}




\section{ATTACHMENT 10}

UMTRA GROUND WATER PROJECT HEADQUARTERS MILESTONES FROM $9 / 92$ to $9 / 99^{\circ}$ (Concluded)

\begin{tabular}{|c|c|c|}
\hline She & Millestone & $\begin{array}{l}\text { Baseline or } \\
\text { forecast dates }\end{array}$ \\
\hline Fourth site & $\begin{array}{l}\text { Initiate site assessment at fourth site } \\
\text { Submit SOWP to NRC and states/tribes at fourth site } \\
\text { Receive approval from NRC on SOWP at fourth site } \\
\text { Publish FONSI/EA at fourth site } \\
\text { Submit final RAP to NRC at fourth site }\end{array}$ & $\begin{array}{l}10 / 01 / 95 \\
12 / 31 / 95 \\
03 / 31 / 96 \\
09 / 30 / 98 \\
09 / 30 / 99 \\
\end{array}$ \\
\hline Fifth site & $\begin{array}{l}\text { Initiate site assessment at fifth site } \\
\text { Submit SOWP to NRC and states/tribes at fifth site } \\
\text { Receive approval from NRC on SOWP at fifth site } \\
\text { Publish FONSI/EA at fifth site }\end{array}$ & $\begin{array}{l}10 / 01 / 96 \\
12 / 31 / 96 \\
03 / 31 / 97 \\
09 / 30 / 99 \\
\end{array}$ \\
\hline Sixth site & $\begin{array}{l}\text { Initiate site assessment at sixth site } \\
\text { Submit SOWP to NRC and states/tribes at sixth site } \\
\text { Receive approval from NRC on SOWP at sixth site } \\
\text { Publish FONSI/EA at sixth site }\end{array}$ & $\begin{array}{l}10 / 01 / 96 \\
12 / 31 / 96 \\
03 / 31 / 97 \\
09 / 30 / 99\end{array}$ \\
\hline Seventh site & $\begin{array}{l}\text { Initiate site assessment at seventh site } \\
\text { Submit SOWP to NRC and states/tribes at seventh site } \\
\text { Receive approval from NRC on SOWP at seventh site }\end{array}$ & $\begin{array}{l}10 / 01 / 97 \\
12 / 31 / 97 \\
03 / 31 / 98 \\
\end{array}$ \\
\hline Eighth site & $\begin{array}{l}\text { Initiate site assessment at eighth site } \\
\text { Submit SOWP to NRC and states/tribes at eighth site } \\
\text { Receive approval from NRC on SOWP at eighth site }\end{array}$ & $\begin{array}{l}10 / 01 / 97 \\
12 / 31 / 97 \\
03 / 31 / 98 \\
\end{array}$ \\
\hline Ninth site & $\begin{array}{l}\text { Initiate site assessment at ninth site } \\
\text { Submit SOWP to NRC and states/tribes at ninth site } \\
\text { Receive approval from NRC on SOWP at ninth site }\end{array}$ & $\begin{array}{l}10 / 01 / 98 \\
12 / 31 / 98 \\
03 / 31 / 99 \\
\end{array}$ \\
\hline
\end{tabular}

- Performance milestones cover FY1993 and FY1994; forecast milestones cover FY1995 to FY1999. Milestones past FY1999 will be included at a later date.

bDue to sensitivity issues surrounding the cooperative agreement between the DOE and the Navajo Nation, the milestone to have approval by NRC on the SOWP on the first site by the end of FY1993 has been slipped to March 31, 1994.

\section{A - Actual.}




\section{UMTRA GROUND WATER PROJECT STAFFING}

PERSONNEL

120

\begin{tabular}{|l|r|r|r|r|r|r|}
\hline & FY93 & FY94 & FY95 & FY96 & FY97 & FY98 \\
\hline $\begin{array}{l}\text { UMTRA PROJECT } \\
\text { OFFICE }\end{array}$ & 2 & 4 & 9 & 14 & 22 & 22 \\
\hline AL MATRIX & 3 & 3 & 3 & 3 & 3 & 3 \\
\hline TAC & 27 & 47 & 54 & 62 & 70 & 75 \\
\hline RAC & 0 & TBD & TBD & TBD & TBD & TBD \\
\hline \multicolumn{1}{|c|}{ TOTAL } & 32 & 54 & 66 & 79 & 95 & 100 \\
\hline
\end{tabular}

a UMTRA PROJECT AUTHORIZED POSITION

TBD - TO BE DETERMINED
(FULL TIME EQUIVALENTS)
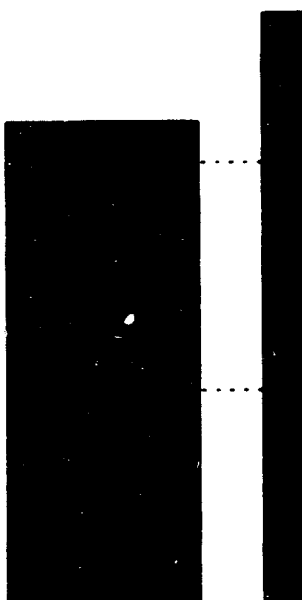
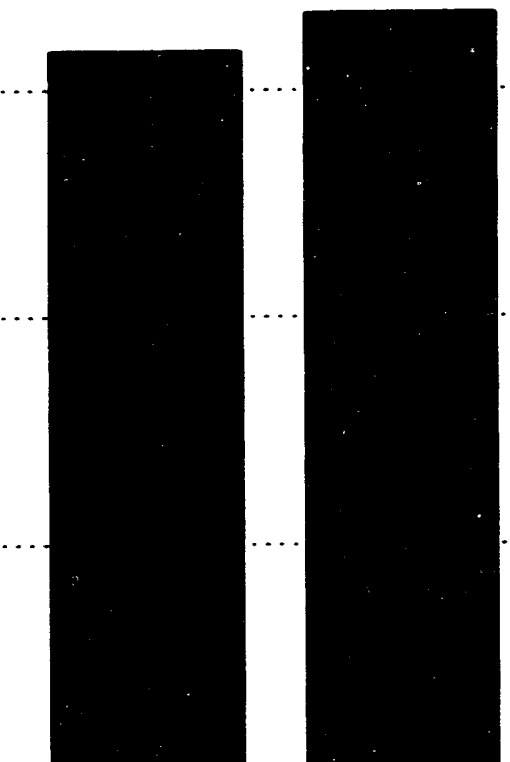

(1)


ATTACHMENT 12

SUMMARY OF UMTRA GROUND WATER PROJECT BASELINE INFORMATION

\begin{tabular}{|c|c|c|c|}
\hline Beseline & $\begin{array}{l}\text { Acquisition executive } \\
\text { (Level 0) }\end{array}$ & $\begin{array}{c}\text { Secretarial/program } \\
\text { (Leved 1) }\end{array}$ & $\begin{array}{l}\text { Project/fileld } \\
\text { (Level 2) }\end{array}$ \\
\hline Technical (scope) & $\begin{array}{l}\text { Comply with EPA ground water } \\
\text { standards at } 24 \text { processing } \\
\text { sites. }\end{array}$ & $\begin{array}{l}\text { Overall Project level: } \\
\text { - Targeted remediation } \\
\text { strateoy. } \\
\text { - Volume and types of ground } \\
\text { water contaminants. }\end{array}$ & $\begin{array}{l}\text { For each site: } \\
\text { - Targeted remediation } \\
\text { strategy. } \\
\text { - Water rights. } \\
\text { - Contaminants. } \\
\text { - Ground water standards. } \\
\text { - Land use and access. }\end{array}$ \\
\hline Schedule & $\begin{array}{l}\text { - Annual ESAR roviews: } \\
\text { FY1994, FY1995, FY1996, } \\
\text { and FY1997. } \\
\text { - Terminate Project by and of } \\
\text { FY2014 with continuation of } \\
\text { natural flushing strategY. }\end{array}$ & $\begin{array}{l}\text { Approval of FONSI and other } \\
\text { NEPA documents for each } \\
\text { site. } \\
\text { - RAP approval for each pump } \\
\text { and treat site and work plan } \\
\text { approval for remaining sites. } \\
\text { - Initiate compliance strateoy at } \\
\text { each site. } \\
\text { - NRC acceptance of } \\
\text { completion report for each } \\
\text { site. }\end{array}$ & $\begin{array}{l}\text { For each site: } \\
\text { - Issue/publish FONSI or other } \\
\text { NEPA documents. } \\
\text { - Initiate final design/RAP for } \\
\text { pump and treat sites and } \\
\text { work plan for remaining } \\
\text { sites. } \\
\text { - Secure site access. } \\
\text { - Implement work plan. } \\
\text { - Acceptance of completion } \\
\text { report. }\end{array}$ \\
\hline Cost & $\begin{array}{l}\text { TEC } \$ 673.4 M \text { federal share. } \\
\text { TPC } \$ 691.6 M\end{array}$ & TPC for each site. & $\begin{array}{l}\text { TPC for each site/contractor } \\
\text { within contingency level. }\end{array}$ \\
\hline
\end{tabular}

ESAR - Energy system acquisition review. 


\begin{tabular}{|c|c|c|c|c|}
\hline \multirow{2}{*}{ 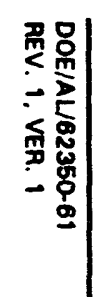 } & \multicolumn{4}{|c|}{$\begin{array}{l}\text { ATTACHMENT } 13 \\
\text { SUMMARY OF UMTRA GROUND WATER PROJECT THRESHOLDS }\end{array}$} \\
\hline & Baseline & $\begin{array}{l}\text { Acquialtion executive } \\
\text { (Level 0) }\end{array}$ & $\begin{array}{c}\text { Secretarial/program } \\
\text { (Level 1) }\end{array}$ & $\begin{array}{l}\text { Projoct/field } \\
\text { (Level 2) }\end{array}$ \\
\hline & $\begin{array}{l}\text { Technical (scope) } \\
\text { (See Attachment } 7 \text { for } \\
\text { details) }\end{array}$ & $\begin{array}{l}\text { - Changes impacting number } \\
\text { of sites or EPA standards. } \\
\text { - Changes impacting state or } \\
\text { local regulators. }\end{array}$ & $\begin{array}{l}\text { Overall project level changes to: } \\
\text { - Remediation strategies. } \\
\text { - Site changes impacting types of } \\
\text { contaminants or concentration of } \\
\text { contaminants. } \\
\text { - Water rights strategies. }\end{array}$ & $\begin{array}{l}\text { Changes for each site } \\
\text { impacting: } \\
\text { - Targeted remediation } \\
\text { strategy. } \\
\text { - Water rights. } \\
\text { - Contaminants. } \\
\text { - Ground water standards. } \\
\text { - Land use and access. }\end{array}$ \\
\hline & $\begin{array}{l}\text { Schedule } \\
\text { (See Attachments } 8 \\
\text { and } 10 \text { for details) }\end{array}$ & $\begin{array}{l}\text { Schedule change of } 1 \text { year } \\
\text { or greater beyond current } \\
\text { Baseline Approved for Use } \\
\text { completion date. }\end{array}$ & $\begin{array}{l}\text { Level 1a: } \\
\text { - Schedule changes >6 months but } \\
\text { <12 months beyond current } \\
\text { Baseline Approved for Use } \\
\text { completion date. } \\
\text { Level 1b: } \\
\text { - Schedule changes >6 months but } \\
<12 \text { months beyond current } \\
\text { Baseline Approved for Use } \\
\text { completion date for level } 1 \\
\text { milestones. }\end{array}$ & $\begin{array}{l}\text { Schedule change } \leq 6 \text { months } \\
\text { beyond current Baseline } \\
\text { Approved for Use completion } \\
\text { date for Level } 1 \text { milestones. } \\
\text { Schedule changes >1 month } \\
\text { beyond current Baseline } \\
\text { Approved for Use completion } \\
\text { date for Level } 2 \text { milestones. }\end{array}$ \\
\hline 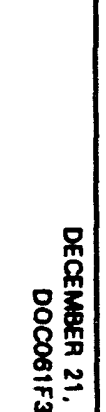 & $\begin{array}{l}\text { Cost } \\
\text { (See Exhibit } 4 \text { for } \\
\text { details) }\end{array}$ & $\begin{array}{l}\text { Cost changes in excess of } \\
\$ 50 \mathrm{M} \text {. }\end{array}$ & $\begin{array}{l}\text { Level 1a: } \\
\text { - Any change in Project TPC } \geq \$ 30 M \\
\text { but }<\$ 50 \mathrm{M} \text {. } \\
\text { Level 1b: } \\
\text { - Any change in Project TPC } \geq \$ 20 M \\
\text { but }<\$ 30 \mathrm{M} \text {. } \\
\text { - Any change in a site TPC } \geq 15 \% \text {. }\end{array}$ & $\begin{array}{l}\text { All proposed cost changes for } \\
\text { which use of Project } \\
\text { contingency is required. } \\
\text { Any change in Project TPC } \\
<\$ 20 M \text {. } \\
\text { Any change in a site TPC } \\
<15 \% \text {. }\end{array}$ \\
\hline
\end{tabular}



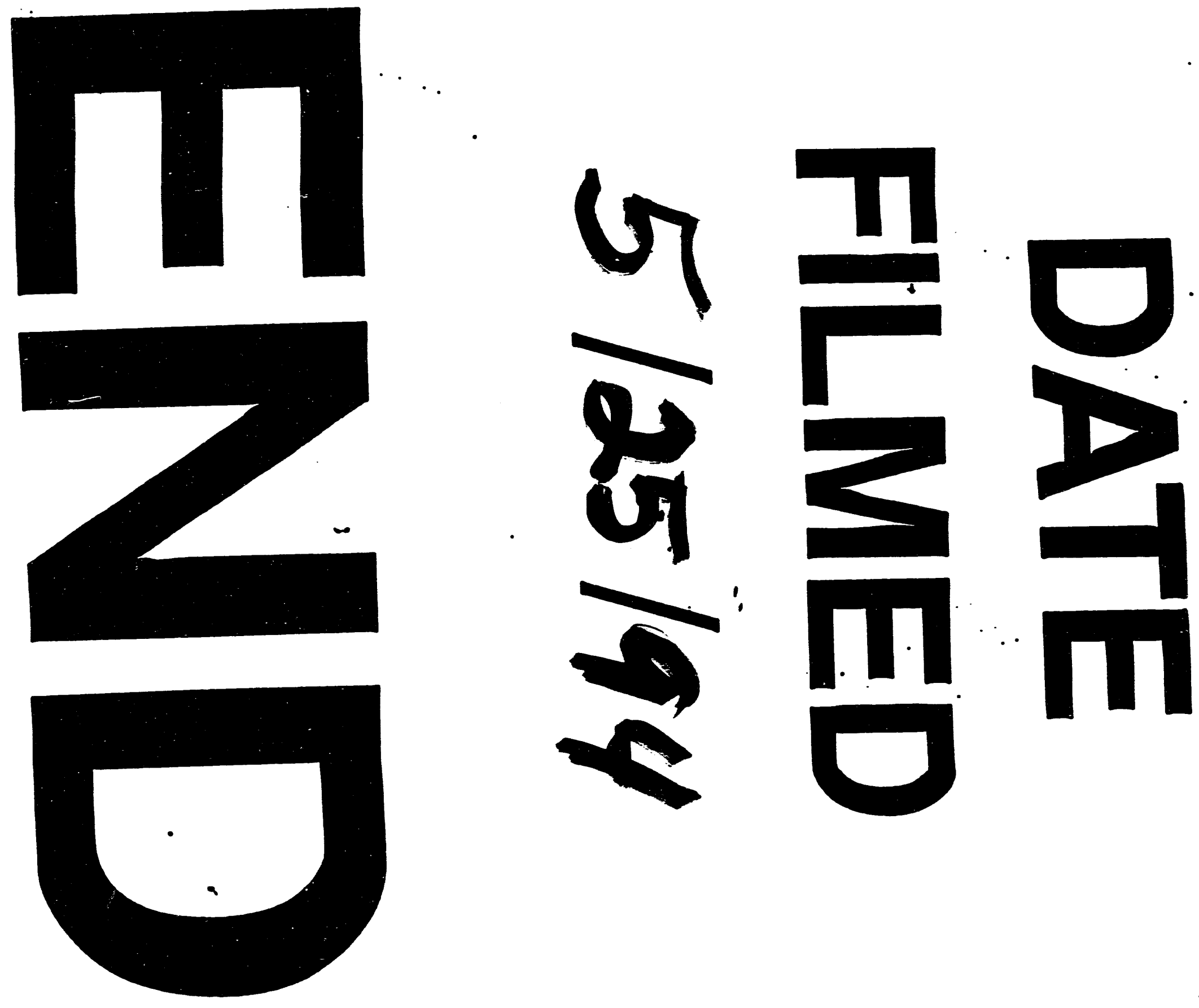
